
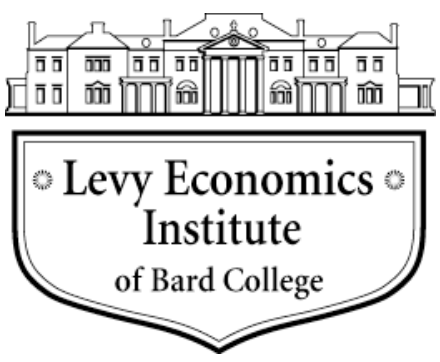

Working Paper No. 756

\title{
Long-Term Benefits from Temporary Migration: Does the Gender of the Migrant Matter?
}

by

\author{
Sanjaya DeSilva* \\ Department of Economics, Bard College \\ Levy Economics Institute of Bard College
}

February 2013

* I am thankful to Juan Bages and Dimin Xu for their excellent research assistance.

The Levy Economics Institute Working Paper Collection presents research in progress by Levy Institute scholars and conference participants. The purpose of the series is to disseminate ideas to and elicit comments from academics and professionals.

Levy Economics Institute of Bard College, founded in 1986, is a nonprofit, nonpartisan, independently funded research organization devoted to public service. Through scholarship and economic research it generates viable, effective public policy responses to important economic problems that profoundly affect the quality of life in the United States and abroad.

Levy Economics Institute

P.O. Box 5000

Annandale-on-Hudson, NY 12504-5000

http://www.levyinstitute.org

Copyright (C) Levy Economics Institute 2013 All rights reserved

ISSN 1547-366X 


\begin{abstract}
Utilizing a nationally representative sample of households from Sri Lanka, this study examines gender differences in the long-term impact of temporary labor migration. We use a propensity score matching (PSM) framework to compare households with return migrants, households with current migrants, and equivalent nonmigrant households in terms of a variety of outcomes. Our results show that households that send women abroad are relatively poor and utilize migration to catch up with the average household, whereas sending a man abroad allows an already advantaged household to further strengthen their economic position. We also find that remittances from females emphasize investment in home improvements and acquisition of farm land and nonfarm assets, whereas remittances of men are channeled more toward housing assets and business ventures.
\end{abstract}

Keywords: Migration; Remittances; Gender; Sri Lanka

JEL Classifications: F22, F24, J61, O15 


\section{INTRODUCTION}

Temporary migrant workers in the Gulf States have become a major source of foreign exchange for several South and Southeast Asian economies. More than two million Filipinos, three million Bangladeshis, six million Indians, and about 800,000 Sri Lankans work in the Middle East. ${ }^{1}$ Women are a large and increasing proportion of this migrant workforce (Cortes 2011). Several countries-Indonesia, the Philippines and Sri Lanka—specialize in the supply of female labor (Oishi 2002); as many as 70-80 percent of migrants to the Middle East from the Philippines and Sri Lanka are women (Huguet 2003; UNDP 2009).

This study focuses on gender differences in the long-term impact of temporary migration. Specifically, we examine whether long-term returns to migration are particularly low for women who are primarily engaged in unskilled domestic work. Since migration to the Middle East is almost always temporary and there are virtually no pathways to permanent immigration, economic gains tend to be short lived unless migrant worker households are able to channel remittances and savings to investments that yield sustained improvements in living standards. Such long term prospects may be undermined by the lack of public scrutiny and legal protection that make female workers especially vulnerable to violation of contracts, abuse, and exploitation (Lim and Oishi 1996; Oishi 2002; Huguet 2003). Unskilled, domestic work provides few opportunities for human capital accumulation and transfer of knowledge that women can utilize following their return home. Lack of financial literacy and social capital, limited opportunities for business investments, and cultural and institutional barriers also constrain the ability of female return migrants to invest remittances productively in selfemployment and asset markets (Koc and Onan 2004). In households that are left behind, the absence of the primary caregiver may inhibit the wellbeing and long-term health and education prospects of the children (Cortes 2011; McKenzie and Rapoport 2011) and intra-household bargaining problems may divert migrant earnings toward uses preferred by other household members (Guzman, Morrison, and Sjöblom 2008; Ashraf et al. 2011; Chin, Karkoviata, and Wilcox 2011). Due to the confluence of such adverse factors, a large disconnect could emerge between the long-term household level impact of female migration and the widely documented

\footnotetext{
${ }^{1}$ This amounts to between a fifth and a fourth of the migrant population in India and the Philippines, and as much as three-fourths of all migrants from Bangladesh.
} 
short-term macroeconomic benefits (Adams and Page 2005; Acosta et al. 2008). ${ }^{2}$ Government policies and regulations regarding female migration have reflected such contradictions (Yeoh, Huang, and Gonzalez 1999); while some developing country governments have actively integrated foreign employment of women to their development agenda, several have restricted the out-migration of women citing the reasons that were previously outlined. ${ }^{3}$

In this study, we utilize household level data from Sri Lanka to examine the long-term impact of temporary overseas migration on a broad range of household outcomes such as income, expenditure, and investments in schooling, housing, assets, and business ventures. Specifically, we use a propensity score matching (PSM) model to estimate the short- and longterm differences in outcomes between households with return migrants of each gender and equivalent nonmigrant households, and between households with current migrants of each gender and equivalent nonmigrant households. We also compute the differences in differences to ascertain whether the advantage of return migrants relative to comparable nonmigrants is greater than the advantage of current migrants relative to comparable nonmigrants. We are especially interested in testing whether gains are particularly low for households of migrant women and whether remittances of women are invested differently from remittances of men.

A primary contribution of this study is the adoption of a broad definition of household investments, with a particular focus on investments in housing stock and household amenities. Whether migration is beneficial or not depends on the lens with which the migration experience is examined. Male and female migrants may have different goals and expectations; investments in schooling, housing, and household amenities are consistently among the primary goals of migrant women (Hoddinott 1994; de la Briere et al. 2002; Guzman, Morrison, and Sjöblom 2008). Even when the ex-ante goals are similar, earnings of female migrants may be allocated to different uses, such as housing, amenities, and schooling, compared to the earnings of male migrants that are invested in financial and physical assets and in entrepreneurial activities when there are constraints on female participation in capital markets and entrepreneurial activities.

\footnotetext{
${ }^{2}$ It is possible for remittance inflows to create a Dutch Disease type situation in which the emergence of more productive export industries are crowded out. See, for example, Acosta, Lartey, and Mandelman (2009) and Lartey, Mandelman, and Acosta (2012).

${ }^{3}$ The Sri Lanka Bureau of Foreign Employment (SLBFE) and the Philippine Overseas Employment Agency (POEA), for example, promote and facilitate the overseas migration of women (Lasagabaster, Maimbo, and Hulugalle 2005; Yang 2011). Migration restrictions for young women or for mothers of young children have been proposed or implemented in the Philippines, Bangladesh, India, and Sri Lanka (Huguet 2003; Cortes 2011).
} 
Many studies (e.g., Gunatilleke 1992) have classified investments in both schooling and housing as unproductive expenditure even though there are clear long-term economic benefits to the household from such investments. In fact, in Gamburd's (2000) study of a Sri Lankan village, both men and women cited the purchase of land and housing as the primary motivation for going abroad. ${ }^{4}$

Our data source, the Sri Lanka Integrated Survey (SLIS) of 1999-2000, has several advantages that make it particularly suitable for this study. It is a nationally representative household-level dataset from one of the few developing countries in which the majority of migrant workers are women. The survey was carried out at a time when the proportion of female migrants was at its peak (Sri Lanka Bureau of Foreign Employment 2009). Sri Lanka provides an especially interesting case study because its female migrants work almost exclusively as unskilled domestic workers in the Middle East. ${ }^{5}$ Since Sri Lankan migrants to the Middle East do not have a path to more permanent forms of immigration, their return decision can be considered exogenous unlike in the often studied cases where the decision to return is voluntary and is subject to observed and unobserved heterogeneity (Gibson and McKenzie 2011). We have detailed data on housing values, housing quality, and household amenities, allowing us to include outcomes that are typically favored by female migrants and overlooked by studies that focus exclusively on financial assets and business investments. The identification of both current and return migrants enables us to assess the long-term impact of migration and the comparison of differences-in-differences between current and return migrants provides us with a means to control for unobserved heterogeneity that differentiates migrants from nonmigrants. The availability of data on education and land ownership of the previous generation, i.e., parents of the householders, provides us with a valid and robust set of pre-migration conditional variables with which migrant households are matched with comparable nonmigrant households.

Our results show that households with return migrants, but not those with current migrants, are better off relative to comparable nonmigrant households. Consistent with a negative selection effect, households with females currently abroad have relatively low

\footnotetext{
${ }^{4}$ In environments with weak and unstable financial markets and high inflation, even consumer durables and jewelry-two uses of remittances that are often dismissed as conspicuous consumption-may turn out to be sound financial investments (Gamburd 2000).

${ }^{5}$ Indonesian and Filipino women have a more diverse range of destinations (e.g., East and Southeast Asia, United States) and occupations (e.g., nursing).
} 
outcomes. Although net long-term gains from migration are generally positive, the gains to women are relatively low and are concentrated in durables, schooling expenditure, amenities, housing quality, land, and farm assets. It appears, however, that migration of females allows relatively poor households to catch up with nonmigrant households in the long run.

\section{LITERATURE REVIEW}

A large number of studies based on remittance use surveys of migrants have generally concluded that a substantial portion of remittances are consumed rather than invested. ${ }^{6}$ While these studies provide richly detailed insights on a specific sample of migrants, the absence of a reference group of nonmigrants makes it difficult to arrive at causal inferences on the impact of migration. By focusing exclusively on how remittances are spent, they also fail to acknowledge the fungibility of household income derived from different sources (Taylor and Mora 2006). Following Adams (1991), a different branch of the literature has included remittance income as an additional variable to a standard system of household demand equations, allowing remittances to have direct and indirect (via household income) effects on household expenditure patterns. ${ }^{7}$ The findings, from developing countries as varied as Egypt, Guatemala, Mexico, and Pakistan, generally dispel the widely held belief that migrant remittances are consumed rather than invested productively. There is evidence from different contexts-e.g., Mexico (Massey and Parrado 1998) and the Philippines (Yang and Martinez 2005; Yang 2008)—-that remittances promote entrepreneurship and business investments. However, by focusing exclusively on remittances, these studies overlook the broader effects of migration that include shifts in the shadow price of home produced goods, changes in information and preferences, changes in the risk profile of household income, changes in the short-term liquidity position, and changes in intra-household decision making dynamics (Taylor and Mora 2006).

In this study, we directly compare household outcomes of migrant households with those of nonmigrant households, placing remittances revenue in the broader context of how migration impacts the household. Using a similar approach, several recent studies have documented a

\footnotetext{
${ }^{6}$ An example is Koc and Onan (2004). See Taylor et al. (1996) and Chami, Fullenkamp, and Jahjah (2003) for reviews of early studies.

${ }^{7}$ Acosta (2006), Yang (2008), and Nguyen and Purnamasari (2011) are recent examples. See Yang (2011) for a review.
} 
complex and ambiguous relationship between migration and children's outcomes (Antman 2011; Amuedo-Dorantes and Pozo 2010; Cortes 2011). Focusing on a broader set of household consumption and investment outcomes and using the migration history of the household to instrument for the current migration decision, Taylor and Mora (2006) find that Mexican households with international migrants have relatively large marginal budget shares for investments, health, and consumer durables and relatively small marginal budget shares for food and housing.

Several studies have examined how the migrant's gender influences the manner in which remittances are utilized. The consensus that emerges from this literature is that female migrants provide insurance for the household left behind and tend to prefer expenditures on education and health, whereas male remitters prefer investments in housing and other assets (Hoddinott 1994; de la Briere et al. 2002; Guzman, Morrison, and Sjöblom 2008). Cortes (2011) uses demand shocks in recipient countries as an exogenous source of variation in the gender composition of migrants to show that migration of females has a relatively higher impact on the educational outcomes of children in the Philippines compared to the migration of males. ${ }^{8}$ On the other hand, the absence of parents, mothers in particular, can have a direct negative impact on children's wellbeing. Cortes (2011) finds that a mother's absence is more detrimental to children than a father's absence. Nguyen and Purnamasari (2011) show that, in Indonesian households, the absence of mothers has no effect on children's education perhaps because the negative effect of the mother's absence is offset by the income transfers and corresponding reductions in child labor. A closely related issue is the gender of the household head. In Ghana, Guzman, Morrison, and Sjöblom (2008) find that female-headed households allocate more resources toward education and health, whereas male-headed households allocate more resources toward buying consumer and durable goods. The difference in the pattern of expenditure is attributed to shifts in power at the intra-household level. It is often the parent that is left behind rather than the migrant that makes decisions on the allocation of remittances. Antman (2011) reports that, when fathers migrate in Mexico, mothers shift resources away from male children to female children and that this pattern is reversed after the father returns.

\footnotetext{
${ }^{8}$ This instrument is not able to identify the decision of household members of either gender to migrate and is applicable only in countries (such as the Philippines, but unlike Sri Lanka or Bangladesh) where there is a large variation in gender composition of out-migrants by host country.
} 
A persistent methodological problem in making causal inferences in migration studies is the nonrandom selection of migrants and those who choose to remit. In nonexperimental studies, the comparison of migrant and nonmigrant households yields biased estimates unless there are adequate controls for both observed and unobserved characteristics that influence migration decisions and household outcomes (McKenzie and Yang 2010). The direction of estimation bias is difficult to presuppose since migrants may possess unobserved attributes that are both positively (e.g., motivation) and negatively (e.g., negative income shocks) correlated with household outcomes (Chiquiar and Hanson 2005; McKenzie and Rapaport 2010; Yang 2011). In the two methods that have been used to construct appropriate comparison groups of migrants and nonmigrants, the propensity score matching (PSM) method controls for observables but not for unobservables, whereas the regression model with appropriate instrumental variables is able to control for both types. In two related instrumental variable (IV) studies, Yang and Martinez (2005) and Yang (2008) relate variation in household level outcomes such as poverty, human capital accumulation, and entrepreneurship with exogenous variation in remittance flows that are caused by host-country specific exchange rate shocks. Acosta (2006) uses migration networks as instruments to show that Cox-Edwards and Ureta's (2003) earlier finding of significant impact of remittances on children's educational attainment in El Salvador is overstated.

There are two advantages of the PSM methodology over regression-based methods (Black and Smith 2004; Ichino, Mealli, and Nannicini 2008). First, in order to properly compare a migrant household with a comparable nonmigrant household, there must be sufficient overlap between the distributions of the observed characteristics of the two groups (Heckman 1997; Heckman, Ichimura, and Todd 1998). Unlike regression models, PSM provides an explicit method with which a common support can be ensured. Second, PSM is a nonparametric estimator that does not depend on restrictive functional form assumptions for identification. In a study that compares different estimation strategies, McKenzie, Gibson, and Stillman (2010) find that estimation bias is lowest in IV regressions with relevant and valid instruments followed by PSM models. In fact, PSM estimates fare better than IV estimates when the instruments are weak. A few recent studies of migration have utilized a PSM estimator. Comparing the pooled set of households that contain both current and return migrants with nonmigrant households in 
Bangladesh, Sharma and Zaman (2009) find a positive impact of migration on consumption, credit, agricultural inputs, and savings, but do not find any significant impacts on health and education expenditures. In another PSM-based study of both temporary and permanent migrants from Moldova, Poppe (2010) finds that migrant households spend more on food and are more likely to own durables and assets than comparable nonmigrants, and that temporary migration has a stronger impact on household expenditure than permanent migration.

When migration is temporary, much of the impact of migration on household outcomes occurs not via remittances sent by current migrants, but through the allocation of funds saved by migrants over several years after their return. For example, Gamburd (2000) reports that poorer migrant households in Sri Lanka tend to allocate more funds to consumption and debt repayment in the short run but are able to gradually invest in the construction of a house over the long run. When migration is temporary and the household impact of migration is observed over many years, ignoring return migrants can also introduce significant biases to the estimation of impact (Sharma and Zaman 2009). Despite this problem, household level studies of the impact of migration have compared current migrants to nonmigrants because household surveys typically do not identify return migrants. ${ }^{9}$

In this study, we adopt the PSM method as our preferred framework since our data do not provide us with a strong identification strategy for an IV approach. Using the PSM framework, on the other hand, we are able to exploit two features of our dataset to establish a causal effect of migration on household investment and consumption decisions. First, the dataset identifies whether an individual is working abroad currently or has ever worked abroad, allowing us to compare households with return migrants to those with current migrants. Second, the decision to return is exogenous since there is no path to permanent immigration for Sri Lankan migrants in the Middle East. Unlike the comparison of either group with nonmigrant households, the comparison of households with return migrants with those with current migrants is not influenced by unobserved heterogeneity in so far as the decision to return is exogenous. For the comparison of migrant—current and return—households with nonmigrant households,

\footnotetext{
${ }^{9}$ Sharma and Zaman (2009) separately identify current and return migrants in a survey they designed to study the causes and consequences of migration in Bangladesh. However, while they examine the causes of migration separately for current and return migrants, their impact estimates are carried out by comparing, using a propensity score matching (PSM) method, the pooled group of current and return migrants with comparable nonmigrants.
} 
we rely on a set of pre-migration matching variables that include education and land ownership status of the previous generation.

We hypothesize that gains from migration are smaller for households that send women rather than men abroad, and that the gains are reflected in asset values for males and in improvements in household amenities and house quality for females. We also hypothesize that the migration of females allows households that lag behind to catch up with nonmigrants, whereas the migration of males allows households that are already advantaged to further enhance their economic position.

\section{DATA AND DESCRIPTIVE STATISTICS}

\section{The Setting}

With about 1.7 million Sri Lankans (about 24 percent of the labor force) working overseas and about 200,000 migrating every year, migrant labor is a dominant feature of the Sri Lankan economic landscape (Sri Lanka Bureau of Foreign Employment 2009). Sri Lanka earns more foreign exchange from remittances than from foreign direct investment (Lasagabaster, Maimbo, and Hulugalle 2005), and in 2009, worker remittances surpassed garments as the leading source of foreign exchange. Remittances make up 36 percent of foreign exchange earnings and 7 percent of the GDP (Central Bank of Sri Lanka 2011). The macroeconomic importance of migrant work is not unique to Sri Lanka. In South and Southeast Asia, the economies of Vietnam, the Philippines, Bangladesh, Nepal, and the Indian State of Kerala depend at least as much on overseas remittances as Sri Lanka (Yang 2011). Where Sri Lanka stands out is in the geographic concentration and demographic, occupational, and skill profile of its migrant workers. Over 94 percent of Sri Lankans working abroad are in the Middle East, the majority (66 percent) is women, and about nine in ten female migrants are employed as unskilled housemaids (Sri Lanka Bureau of Foreign Employment 2009). Although the proportion of women has gradually fallen since reaching a peak of 75 percent in 1997, approximately half of migrant departures continue to be women (Sri Lanka Bureau of Foreign Employment 2009). Unlike migrants to Europe, North America, Southeast Asia, and Australia, virtually all migrants to the Middle East return to Sri Lanka once the work contract ends. The relative homogeneity of the female migrant experience makes Sri Lanka a particularly interesting and suitable setting to 
evaluate the merits of temporary overseas migration of unskilled women from the perspective of the household.

\section{The Survey}

Modeled on the Living Standards Measurement Surveys of the World Bank, the Sri Lanka Integrated Survey (SLIS) of 1999-2000 contains detailed socioeconomic information on a nationally representative sample of 7,500 households that contain 26,420 individuals aged 14 years or older. ${ }^{10}$ In the sample, there are 701 women and 486 men that have ever worked abroad, of which 427 women and 260 men have returned. Of the 7,500 households, 257 had at least one man and 410 had at least one woman that has returned, whereas 215 households had at least one man and 261 had at least one woman that is currently abroad. The survey covers a time period in which the proportion of female migrants was at its highest levels (Sri Lanka Bureau of Foreign Employment 2009).

Each household head was asked whether any household member above age 14 ever worked abroad. For those that are currently working abroad, information is available on the type of work, industry, and occupation, the country of migration, year of migration, and the amount of remittances sent last year. This information is not available for return migrants. ${ }^{11}$ The profile of current migrants reported in Table 1 is consistent with our premise that women migrate overwhelmingly to the Middle East, that the duration of migration is short ( 98 percent of current migrants have been abroad for five years or less) and that women remit less (about two-thirds as much) money than their male counterparts.

\section{Outcomes}

Much of the empirical literature has examined whether remittances are invested or consumed. To this end, we examine the impact of migration on per capita income, per capita expenditure, value of durables, expenditure share on adult goods and schooling, holdings of assets and debt, and participation in entrepreneurial activities. Consumer durables include goods such as televisions, radios, and furniture, whereas adult goods refer to tobacco, alcohol, betel leaves, and

\footnotetext{
${ }^{10}$ See External Resources Department of Sri Lanka (2010) for details.

${ }^{11}$ There is also no information about households that have migrated, but this is not a problem for the purposes of this study because almost all migrant workers to the Middle East migrate as individuals.
} 
eating out. When intra-household bargaining problems and time inconsistency problems are present, remittances may be allocated disproportionately to consumer durables and adult goods rather than to assets and business investments. There is also a gender element to the consumption of adult goods since tobacco and alcohol, in the Sri Lankan context, are almost exclusively consumed by men.

We include schooling and housing as two important forms of investment that improve a household's long-term economic prospects and quality of life (Taylor and Mora 2006). This is in contrast to the literature that, barring a few exceptions (Calero, Bedi, and Sparrow 2009; Cortes 2011), has by and large treated educational expenditure as a form of consumption rather than as a "productive investment" since it does not result in the immediate employment of resources (Koc and Onan 2004). Our proxy for educational investments is the expenditure share on schooling. Very few studies (e.g., Taylor and Mora 2006) formally examine the impact of migration on housing. A major contribution of our study is the inclusion of four different aspects of housing investments: homeownership, value of housing, the material quality of housing, and household amenities. Traditionally, rural Sri Lankan houses are built with mud walls, earth floors, and palm-leaf roofs and do not have modern toilets, electric lighting, and gas or electric stoves. There has been considerable modernization of the housing stock in the past few decades, and migrant earnings are used by households lagging behind to catch up in this regard (Gamburd 2000). Specifically, we examine indicator variables for whether the house has a flush toilet, electric lighting, and electric or gas stove and material quality indicators that tell us whether the floor of the house is made from cement, wood, brick, or tiles (rather than earth or clay), whether the wall is made from brick or cement (rather than mud, planks, metal, or traditional materials), and whether the roof is made from tiles, asbestos, or metal sheets (rather than traditional materials). The housing and amenity variables are particularly important to our analysis since qualitative studies have documented that Sri Lankan migrants place investments in housing at the top of their list of reasons for choosing to migrate (Gamburd 2000). Table A1 (in the appendix) lists the dependent variables and reports descriptive statistics by migration status of the household. The differences in outcomes between the groups will be discussed in detail in the results section. 


\section{METHODOLOGY}

The basic idea of the PSM method is to estimate the average treatment (migration) effect on the treated (migrant households). For an outcome Y, the expected treatment (i.e., migration) effect on the treated (i.e., migrant households) that is observed t periods after treatment $\left(A T T_{t}\right)$ is

$A T T_{t}=E\left(Y_{t}-Y_{0} \mid M\right)=E\left(Y_{t} \mid M\right)-E\left(Y_{0} \mid M\right)$

where $\mathrm{M}$ denotes whether the household has ever sent a migrant overseas. The pre-migration outcome of migrant households $E\left(Y_{0} \mid M\right)$ is a counterfactual in cross-sectional data such as ours. We are interested in two durations, the short and long term. Short term $(t=1)$ is defined as the time period where at least one household member is currently abroad and the long term $(t=2)$ is a sufficiently long duration where all migrants have returned. Our dataset distinguishes nonmigrant households (0), households with migrants currently abroad (C), and households with return migrants $(\mathrm{R})$ and the corresponding outcomes $Y_{0}, Y_{C}, Y_{R}$ are observed. In most migration studies, the long-term impact is difficult to measure since some migrants do not return and $Y_{2}$ is typically not observed for those that have chosen not to return. A further complication arises if those who return are not randomly selected. Our data are not affected by these problems because a vast majority of migrant workers (97 percent of women) in our sample are employed in the Middle East as temporary workers and do not face a viable option of remaining in their host countries beyond the short contract; 98 percent of current migrants have been overseas for five years or less. Specifically, we exploit the unique attributes of the Sri Lankan context in two ways. First, the fact that all migrants return in the long run allows us to assert that $E\left(Y_{1} \mid M\right)=E\left(Y_{C} \mid M\right)$ and $E\left(Y_{2} \mid M\right)=E\left(Y_{R} \mid M\right)$. Second, since the return decision is exogenous and consequently uncorrelated with the determinants of the decision to migrate, i.e. $Y_{0}, Y_{1}, Y_{2} \perp$ $R, C \mid M$, we use the average outcomes of the current migrants and return migrants at a given time as proxies for the average outcomes in the short and long run for the entire sample of migrants, i.e., $E\left(Y_{C} \mid M\right)=E\left(Y_{C} \mid C\right)$ and $E\left(Y_{R} \mid M\right)=E\left(Y_{R} \mid R\right)$.

The comparison of migrants with nonmigrants relies on the unrealistic assumption that the assignment of the treatment of migration is random, i.e., $E\left(Y_{0} \mid M\right)=E\left(Y_{0} \mid 0\right)$. However, if there is a set of exogenous variables $(\mathrm{X})$ such that, conditional on $\mathrm{X}$, household outcomes are 
independent of the treatment assignment, i.e., $Y_{R}, Y_{C}, Y_{0} \perp M \mid X$, we can estimate the counterfactual ATT, $E\left(Y_{t} \mid M\right)-E\left(Y_{0} \mid M\right)$, with $E\left(Y_{t} \mid M, X\right)-E\left(Y_{0} \mid 0, X\right)$, the difference in outcomes between migrants and a set of matched nonmigrants with identical pre-migration attributes (X) (Sharma and Zaman 2009; McKenzie, Gibson, and Stillman 2010; Poppe 2010). The crucial identifying assumption of the PSM methodology, known variously as conditional independence (Lechner 1999), selection on observables (Barnow, Cain, and Goldberger 1980), and ignorable treatment (Rosenbaum and Rubin 1983), is that the assignment of households to the treatment (i.e., migration) is based entirely on a set of observed pre-migration attributes. The conditional independence assumption depends on the availability of a large and informative set of pre-treatment independent variables (X) with which migrant households can be matched with fully equivalent nonmigrant households. With a good set of exogenous pre-migration variables, the PSM estimator does better than OLS and has been found to outperform IV regressions with relatively weak instruments (McKenzie, Gibson, and Stillman 2010).

We use the characteristics of the household head and his or her parents, demographic composition of the household, ethnicity, and the sector and province of residence as our conditioning independent variables. A complete list of variables and their descriptive statistics are reported in Table A2 in the appendix. Our dataset has the advantage of containing three crucial variables about the generation that preceded the household head; we know whether the parents of the household head and of his or her spouse attended school and owned land. In a developing economy such as Sri Lanka where factor markets are imperfect and intergenerational mobility is limited, attributes of the earlier generation are particularly useful determinants of the household's pre-migration economic conditions and the decision to migrate.

For computational simplicity, the PSM method matches current and return migrants (treatment) with nonmigrant (control) households based on one-dimensional propensity scores

$\pi_{C}(X)=P(C=1 \mid X) ; \pi_{R}(X)=P(R=1 \mid X) ; 0 \leq \pi_{C}(X), \pi_{R}(X) \leq 1$

that are predicted from the multi-dimensional set of $\mathrm{X}$ variables using a probit regression (Rosenbaum and Rubin 1983). The independence of outcomes and treatment conditional on $\mathrm{X}$ 
implies that the outcomes and treatment are independent conditional on $\pi(X)$. Therefore, the estimated ATT in the PSM model is

$$
\begin{aligned}
& A T T_{1}=E\left(Y_{1}-Y_{0} \mid M\right)=E\left(Y_{C} \mid C, \pi_{C}(X)\right)-E\left(Y_{0} \mid 0, \pi_{C}(X)\right) \\
& A T T_{2}=E\left(Y_{2}-Y_{0} \mid M\right)=E\left(Y_{R} \mid R, \pi_{R}(X)\right)-E\left(Y_{0} \mid 0, \pi_{R}(X)\right)
\end{aligned}
$$

Using 1,000 randomly drawn sub-samples, we also construct bootstrapped standard errors that correct for the fact that propensity scores used to construct the matched sample are themselves estimated. Although the availability of an appropriate set of $\mathrm{X}$ variables allows us to construct the counterfactuals using PSM reasonably well, it is difficult to eliminate all unobservable differences that differentiate households with migrants from nonmigrant households. Examples of such unobservables are ambition, motivation, innate abilities, and social capital that may be independently correlated with the outcomes of interest, such as expenditure on schooling and homeownership. However, provided that the decision to return is exogenous, the unobservable attributes of all migrant households, regardless of whether the migrants have returned or not, are likely to be similar. Therefore, we contend that the estimation bias in ATTs estimated by (3a) and (3b) that is caused by unobservable differences between nonmigrant and migrant households is similar in magnitude. Specifically, the bias (B) should be approximately the same in each equation.

$$
\begin{aligned}
& A T T_{1}+B=E\left(Y_{C} \mid C, \pi_{C}(X)\right)-E\left(Y_{0} \mid 0, \pi_{C}(X)\right) \\
& A T T_{2}+B=E\left(Y_{R} \mid R, \pi_{R}(X)\right)-E\left(Y_{0} \mid 0, \pi_{R}(X)\right) \\
& \text { where } B=E\left(Y_{0} \mid C, \pi_{C}(X)\right)-E\left(Y_{0} \mid 0, \pi_{C}(X)\right)=E\left(Y_{0} \mid R, \pi_{R}(X)\right)-E\left(Y_{0} \mid 0, \pi_{R}(X)\right) .
\end{aligned}
$$

The difference in difference is

$$
A T T_{2}-A T T_{1}=\left[E\left(Y_{C} \mid C, \pi_{C}(X)\right)-E\left(Y_{0} \mid 0, \pi_{C}(X)\right)\right]-\left[E\left(Y_{R} \mid R, \pi_{R}(X)\right)-E\left(Y_{0} \mid 0, \pi_{R}(X)\right)\right]
$$

The difference in difference measure $\left(A T T_{2}-A T T_{1}\right)$ estimates the difference between the advantage return migrant households have over their observationally equivalent nonmigrant counterparts and the advantage current migrant households have over their observationally 
equivalent nonmigrant counterparts. It provides us with an unbiased estimator for the incremental causal effect of return migration, or the additional long-term impact over and above the short term impact. If we make the additional assumption that there are no short-term gains for some household outcomes, i.e., $A T T_{1}=0$, we can use equation (4a) to measure the bias caused by the nonrandom assignment of migration and equation (5) to obtain an unbiased estimate of the long-term causal effect of migration. The assumption of limited gain during the migrant's overseas stay is reasonable for investments in housing, assets, and business that tend to occur in the long run, typically following the migrant's return, in the Sri Lankan context of temporary migration for short durations.

We prefer the difference in difference measure to the direct comparison of matched current migrant and return migrant households because of the intuitive appeal of the interpretation that was already mentioned and also because of requirement in PSM to achieve common support. As the nonmigrant group is by far the largest and most heterogeneous group, drawing an observationally similar sub-sample to each of the other groups is easier than directly comparing the two migrant groups. Additionally, the overlap in the support of the conditioning variables is likely to be smaller among the two migrant groups because return migrants are typically older and from a different cohort than current migrants. To ensure that the common support condition holds, we trim 5 percent of the distribution at both ends.

\section{RESULTS}

The estimation is carried out using the psmatch 2 module of STATA ${ }^{12}$. We first estimate probit equations for the likelihood that households have a migrant of each type-return and currentand each gender as a function of the control variables. ${ }^{13}$ The results, reported in Table A3 in the appendix, reveal several patterns: Women are more likely to migrate from households that have more women and those that are relatively less educated, landless, and of the Moor ethnicity. Men are more likely to migrate from households that have more men and those that are relatively more educated, urban, and from Tamil and Moor minorities. The propensity scores,

\footnotetext{
${ }^{12}$ See Leuven and Sianesi (2003) for a detailed description of the module.

${ }^{13}$ Since our goal is to find subsets of nonmigrant households with the same exogenous characteristics as each of these groups, probit equations are estimated for samples that contain the relevant group and nonmigrant households with all other households omitted.
} 
$\pi_{C}(X)$ and $\pi_{R}(X)$, obtained from the probit regressions, are then used to match households from each of the four migrant categories with similar nonmigrant households. We utilize the kernel matching approach but verify whether the results are robust under different matching methods.

Table 2 compares the mean values, in matched and unmatched samples, of the control variables for migrant (treatment) and nonmigrant (control) households. The estimates were obtained using the pstest procedure in the psmatch2 module of STATA. For each variable, the p-value of a t-statistic that tests for significant differences between the two groups is also reported. The unmatched means of the treated groups are simply the sample means by migrant type. ${ }^{14}$ Although the differences in unmatched means mirror the results of the probit model, several statistically significant differences are worth emphasizing. Male migrants disproportionately come from households that have a large number of male and female adults in the 31-60 age group, households that are relatively educated (both in terms of the education of the household head and of the previous generation), and households that are urban. Female migrants disproportionately come from households that have a large number of female adults (in the 17-30 and 31-60 age groups) and from households with relatively less educated heads. Migrants of both genders are more likely to come from households that have historically not owned land (as measured by land ownership status of the father of the household head). A relatively large proportion of current migrants belong to ethnic minorities (especially Sri Lankan Tamils and Moors) and male migrants are more likely to come from ethnic minorities than female migrants. Among both males and females, there is a greater concentration of Sri Lankan Tamils and those from the Northern and Eastern provinces (where Sri Lankan Tamils are concentrated) among current migrants. This is not surprising given the ethnic conflict that has restricted the return of Sri Lankan Tamil migrants. Other than for this difference, the samples of return and current male migrants are not qualitatively different, and the decision to return appears to be exogenous as we have asserted. However, there are a few significant qualitative differences between current and return female migrants. Notably, women that are currently abroad are more likely to come from families that are historically less educated and from rural areas. The goal of the PSM method is to adjust for such differences, creating a control group

\footnotetext{
${ }^{14}$ Even though nonmigrant households are always the control group, the mean values for the control group is slightly different because each probit model omitted a few observations from the sample that are off support and those with perfectly predicted successes or failures.
} 
that is equivalent, in terms of independent variables, to the treatment group. Except for two Province dummies, none of the means of matched treatment and control groups are significantly different. ${ }^{15}$ The diagnostics (mean bias, pseudo R squared, and the Chi square test statistic) reported at the end of Table 2 confirm that the matching is carried out successfully, and that the treatment and control groups are observationally equivalent.

Table 3 reports the differences in mean outcomes between treatment (migrant) and control (nonmigrant) households in matched and unmatched samples. The mean differences in outcomes in the unmatched samples-equivalent to differences in sample means between migrants of each type and nonmigrants-reveal several interesting general patterns and provide preliminary answers to several of our hypotheses: 1) Return migrant households are generally better off compared to current migrant households. The advantages are especially significant for expenditure, value of durables, home value, home amenities, housing quality, nonfarm assets, and business ownership for females, and for the same variables, except amenities and housing quality, for males. Only in terms of adult good expenditure (for males), homeownership (for females) and floor quality (for males) are return migrant households worse off compared to current migrant households. 2) Current male migrants come from households that are generally better off than nonmigrant households (especially in terms of housing quality, amenities, and nonfarm assets) except in two important areas: landownership and debt. 3) Households with current female migrants are worse off than nonmigrant households in terms of expenditure, value of durables, adult good consumption, amenities, housing quality, and land cultivated, and better off only in terms of homeownership. 4) Households with male return migrants are better off across the board (with the one exception of land cultivated) compared to households with female return migrants. The relatively unfavorable outcomes of households with current female migrants suggest that the gains from migration accrue to households of female migrants mostly after their return or that there is a negative selection of female migrants. The relatively favorable outcomes of households with male current migrants vis-a-vis their nonmigrant counterparts may be due to gains from migration that accrue while the migrant is abroad or relatively favorable pre-migration characteristics. Both explanations are plausible in the Sri Lankan context: male

\footnotetext{
${ }^{15}$ The matching is successful even at the 10-percent level, with significant differences in only three provincial dummies and in the proportion of women in the 17-30 age group for households that have female migrants currently abroad.
} 
migrants come from a wider skill distribution and work in a variety of locations and occupations, whereas female migrants are overwhelmingly dominated by unskilled domestic workers in the Middle East. Among men, migrants clearly come from relatively advantaged circumstances and migration appears to provide them with an opportunity to further enhance their advantaged position by acquiring productive assets. The migration of a man may benefit his household more rapidly than that of a female migrant not only because his earnings are higher but also because intra-household incentive problems are typically less acute when the man is absent than when the woman is absent.

We then compute the mean differences between the matched samples and the p-value of the t-statistic that tests whether these differences are statistically significant. The matched sample provides a correction for nonrandom selection of migrants based on the observables. We also report the difference in difference between return and current migration. Provided that the gains from migration are largely realized following the migrant's return, the difference in differences can be interpreted as an unbiased estimate of the long-term gains from migration. The results are summarized in the remainder of this section.

\section{Income and Expenditure}

Although households with female migrants currently abroad are not poorer than matched nonmigrant households in terms of annual income, they spend Rs. 411 less per capita and have Rs. 20,184 less in durables. In contrast, households with female return migrants have Rs. 316 higher per capita expenditure compared to matched nonmigrant households and are statistically equivalent in terms of the value of durables owned. The difference-in-difference is insignificant for household income but larger by Rs. 727 (a 51 percent increase) for household expenditure and by Rs. 28,848 (a 66 percent increase) for the value of durables. We do not find significant differences in the share of expenditure on schooling; schooling expenditure increases but only in proportion to the increase in overall expenditure. The share of expenditure on adult goods is substantially and significantly higher (7 percent) when females are abroad but reverts to the mean upon their return. This is indicative of a temporary misallocation of household budgets toward adult goods while the female migrant is absent. 
Households with male migrants currently abroad are statistically equivalent to matched nonmigrant households in terms of income, expenditure, value of durable goods, and the expenditure share on schooling. Households with male return migrants, however, earn Rs. 1,770 more per capita, spend Rs. 786 more per capita, and own durables that are worth Rs. 180,962 more than matched nonmigrant households. The differences-in-differences between return and current migrants relative to their nonmigrant counterparts suggest that there are longterm gains to male migrants in terms of overall expenditure (of Rs. 883 or 43 percent) and ownership of durables (of Rs. 178,052 or 178 percent). We do not find significant effects on per capita income or on the share of expenditure on schooling, as in the case of female migrants. For adult goods, there is a substantial and significant decrease (of 8.11 percent) in the expenditure share while male migrants are abroad, but it reverts to the mean for return migrants. The temporary drop in adult good consumption is consistent with the absence of an adult male, the primary consumers of alcohol and tobacco. Social norms in Sri Lanka make the consumption of alcohol and tobacco almost exclusively an activity of males. Eating out (in bars and restaurants) is also an activity predominantly done by males unless accompanied by the families. Betel leaves are consumed by both men and women, but the typical budget share on betel leaves is significantly less than that of alcohol and tobacco.

\section{Housing}

Although households with female migrants currently abroad are 5 percent more likely to own a home, their home value is Rs. 95,975 lower on average. The quality and amenities of their houses are statistically equivalent to those of matched nonmigrant households except for a slightly lower (3.5 percent) likelihood of having a gas or electric stove. The homeownership rate and mean home value are statistically not different between households with return female migrants and their nonmigrant counterparts. However, they are consistently more likely to have better housing quality and are more likely to have electric lighting and stoves. Differences-indifferences show substantial improvements in the likelihood of cement floors (7.33 percent) and gas and electric stoves ( 9.12 percent), although there is a marginally significant decrease in the availability of flush toilets. 
Households with male migrants currently abroad are similar to their matched nonmigrant counterparts in terms of homeownership and housing value. In terms of housing quality and amenities, they are, across the board, better off. Households with return male migrants, on the other hand, are 4.5 percent more likely to own a home and have a substantially higher (by Rs. $1,197,527)$ house value compared to their nonmigrant counterparts. There are also, across the board, better off in terms of housing quality and amenities. Differences-in-differences show that migration results in a 6.5 percent increase in the homeownership rate, a 187 percent (Rs. $1,146,009)$ increase in house value. Substantial qualitative improvements are observed only for the availability of stoves (by 7.39 percent). In fact, the likelihood of wall and floor quality is significantly lower. It appears that most households with male migrants had high housing quality and amenities to begin with and that these advantages have been generally sustained in the long run.

\section{Assets and Business Activity}

Households with female migrants currently abroad have 0.36 hectares less of farm land, but also have Rs. 6780 less debt compared to their nonmigrant counterparts. The asset and business profile of households with female return migrants is statistically equivalent to matched nonmigrant households. Differences-in-differences show that female migration is associated with the acquisition of farm land ( 0.3 hectare increase), substantial (albeit marginally significant) gains in nonfarm assets (Rs. 45,000 or 128 percent) but no increase in the engagement in business activities.

Households with male migrants currently abroad have 0.36 hectares less in farm land, 5.24 percent less likely to engage in self-finance business and hold Rs. 6547 less in farm assets compared to matched nonmigrant households. However, there is an advantage of Rs. 44,387 in terms of nonfarm assets. Households with male return migrants own 0.1964 less farm land, but are 10.4 percent more likely to own a business and 9.52 percent more likely to own a selffinanced business. They also hold Rs. 133,893 more in assets and hold Rs. 38,601 more in debt. Differences-in-differences show statistically significant gains in the range of 15-16 percent in business ownership. 


\section{DISCUSSION AND CONCLUSIONS}

The propensity score matching estimates reveal that female migration results in substantial (in the 40-60 percent range) long-term increases in household expenditure and the value of durables, no permanent increase in income, and a temporary increase in adult good consumption during a woman's absence. There are also significant but modest gains (6-10 percent range) in housing quality and home amenities in the long run. The most pronounced gains are in the more than doubling of nonfarm asset holdings and in the acquisition of agricultural land. For female migrants, there are no long-term gains in business activity.

Male migration also brings similar increases in expenditure and a considerably larger increase (almost threefold) in the holding of durables. There is a temporary decrease in adult good consumption during a man's absence. In the long run, male migration also results in some

gains in homeownership (of about 6 percent), significant gains in home value (almost threefold), and an increase in the business ownership rate by about 15-16 percent.

The low income gains in the long run are consistent with the fact that temporary migration to the Middle East provides an additional income stream only in the short term and does not typically help migrants to acquire human capital that can be utilized following their return home. The permanent increases in household expenditure and the accumulation of durables appear to be financed from increased holdings of nonfarm assets and farm land for women, and from holdings of housing assets and new business ventures for men.

An important contribution of this study is the documentation of investments in the home and in the schooling of children, two areas often emphasized by female migrants but overlooked in many impact studies. Female migrants are particularly likely to channel resources toward improving the physical quality of the home and toward improvement in household amenities. As observed by Gamburd (2000), these effects are observed mostly in the long term, following the return of the women. Such amenity improvements not only have a direct impact on improving the quality of life of household members, but also have positive effects on improving the efficiency of home production and spillover benefits on education and health outcomes. There are also direct benefits to human capital accumulation, with schooling expenditure increasing in proportion to the increase in overall expenditure of about 40-60 percent. 
Clearly, increased household expenditure is not completely frittered away for consumption goods and durables. In fact, the pronounced changes in adult good consumption are temporary and do not persist after the return of migrants. In the short run, the asymmetry in the adult good consumption may be a consequence of the shifting bargaining power in the allocation of the household budget depending on the gender of the migrant and the gender of the decision-maker that is left behind. As observed in previous studies, household budget controlled by a woman is allocated very differently, typically in favor of expenditure that benefit children and away from the consumption adult goods, than a budget controlled by a man (Guzman, Morrison, and Sjöblom 2008; Cortes 2011).

Temporary migration also leads to long-term improvements in the household's asset position. Households with migrants currently abroad have less landholdings and farm assets than nonmigrant households. The lack of cultivable land and farm assets appears to be a motivation to send household members abroad for two reasons: 1) if the land-labor ratio is low, the household has an incentive to supply labor for migrant work; and 2) when credit markets are weak, migration provides households with the means to purchase lumpy capital goods and land. Male migrants, but not female migrants, divest from agriculture and use remittance savings to start new business ventures. Migration does not significantly improve the household's debt position for either gender. In fact, there is some evidence that the debt situation worsens with return male migrants having an especially high outstanding debt burden. It is possible that the positive effect of remittances on the repayment of old loans is offset by the debt incurred to finance migration.

Our analysis unfolds a broad portrait of how the profile of migrant households and the long-term impact of migration differ by the gender of migrants. Households that send women abroad are relatively poor and utilize migration to catch up with the average household in several respects, whereas sending a man abroad allows an already advantaged household to further strengthen their economic position. We also see that remittances from females are allocated somewhat differently, with an emphasis on investments in the home, farm land, and nonfarm assets, than remittances of men that are channeled more toward housing assets and business ventures. 
Two important implications are worth emphasizing in conclusion. The first implication is that it is important to look beyond the obvious measures such as income and expenditure to accurately gauge the long-term impact of migration. Particularly in the case of female migrants, improvements in the home environment, acquisition of assets, and investments in schooling are important long-term goals of migration. Unless a broad lens that incorporates such multifaceted goals is utilized to examine the migration experience, researchers and policymakers are likely to underestimate the benefits from female migration. The second implication is that female migration appears to be a poverty alleviation strategy for households that have a surplus of women but a shortage of productive assets, whereas male migration is not as much a response to poverty as it is a means of strengthening an already advantaged economic position. If domestic policies are enacted to improve employment prospects of rural women and alternative opportunities for asset accumulation become available in the countryside, the much documented social and psychological costs of migrant work — both for the women and the families that are left behind-can be prevented. 


\section{REFERENCES}

Acosta, P. A. 2006. "Labor Supply, School Attendance and Remittances from International Migration: The Case of El Salvador." World Bank Policy Research Working Paper No. 3903. Washington, DC: World Bank.

Acosta, P. A., C. Calderon, P. Fajnzylber, and H. Lopez. 2008. "What Is the Impact of International Remittances on Poverty and Inequality in Latin America?" World Development 36(1): 89-114.

Acosta, P. A., E. K. K. Lartey, and F. S. Mandelman. 2009. "Remittances and the Dutch Disease." Journal of International Economics 79(1): 102-16.

Adams, R. 1991. "The Economic Uses and Impact of International Remittances in Rural Egypt." Economic Development and Cultural Change 39(4): 695-722.

Adams, R.H. and J. Page. 2005. "Do International Migration and Remittances Reduce Poverty in Developing Countries?” World Development 33(10): 1645-69.

Amuedo-Dorantes, C. and S. Pozo. 2010. “Accounting for Remittance and Migration Effects on Children's Schooling.” World Development 38(12): 1747-59.

Antman, F. 2011. "International Migration and Gender Discrimination among Children Left Behind." American Economic Review 101(3): 645-49.

Ashraf, N., D. Aycinena, and C. Martinez, and D. Yang. 2011. Remittances and the Problem of Control: A Field Experiment among Migrants from El Salvador. Unpublished Manuscript. Ann Arbor, MI: University of Michigan.

Barnow, B., G. Cain, and A. Goldberger. 1980. "Issues in the Analysis of Selectivity Bias.” In E. Stromsdorfer and G. Farkas (Eds.), Evaluation Studies Review Annual, Vol. 5, pp. 42-59. Beverly Hills, CA: Sage.

Black, D. and J. Smith. 2004. "How Robust is the Evidence on the Effects of College Quality? Evidence from Matching." Journal of Econometrics 121(1): 99-124.

Calero, C., A. Bedi, and R. Sparrow. 2009. "Remittances, Liquidity Constraints and Human Capital Investments in Ecuador.” World Development 37(6): 1143-54.

Chami, R., C. Fullenkamp, and S. Jahjah. 2003 “Are Immigrant Remittance Flows a Source of Capital for Development?” International Monetary Fund Working Paper 03/189. Washington, DC: International Monetary Fund.

Central Bank of Sri Lanka. 2011. Annual Report of the Central Bank of Sri Lanka. Colombo: Sri Lanka.

Chin, A., L. Karkoviata, and N. Wilcox. 2011. Impact of Bank Accounts on Migrant Savings and Remittances: Evidence from a Field Experiment. Unpublished Manuscript. Houston, TX: University of Houston.

Chiquiar, D., and G. H. Hanson. 2005. "International Migration, Self-selection, and the Distribution of Wages: Evidence from Mexico and the United States." Journal of Political Economy 113(2): 239-81. 
Cortes, P. 2011. The Feminization of International Migration and Its Effects on the Children Left Behind: Evidence from the Philippines. Unpublished Manuscript. Boston, MA: Boston University.

Cox-Edwards, A. and M. Ureta, 2003. "International Migration, Remittances, and Schooling: Evidence from El Salvador.” Journal of Development Economics 72(2): 429-61.

de la Briere, B., A. de Janvry, E. Sodoulet, and S. Lambert. 2002. "The Roles of Destination, Gender, and Household Consumption in Explaining Remittances: An Analysis for the Dominican Sierra." Journal of Development Economics 68(2): 309-28.

External Resources Department of Sri Lanka. 2010. Sri Lanka Integrated Survey (SLIS). http://www.erd.gov.lk/publicweb/ERDDOCS.html

Gamburd, M. R. 2000. The Kitchen Spoon's Handle: Transnationalism and Sri Lanka's Migrant Housemaids. Ithaca, NY: Cornell University Press.

Gibson, J. and D. McKenzie. 2011. "The Microeconomic Determinants of Emigration and Return Migration of the Best and Brightest: Evidence from the Pacific." Journal of Development Economics 95(1): 18-29.

Gunatilleke, G. (Ed.) 1992. The Impact of Labour Migration on Households: A Comparative Study in Seven Asian Countries. Vol. 3. Tokyo, Japan: United Nations University Press.

Guzman, J. C., A. R. Morrison, and M. Sjöblom. 2008. "The Impact of Remittances and Gender on Household Expenditure Patterns: Evidence from Ghana.” In A. R. Morrison, M. Schiff, and M. Sjöblom (Eds.), The International Migration of Woman. Washington, DC: World Bank.

Hoddinott, J. 1994. "A Model of Migration and Remittances Applied to Western Kenya." Oxford Economic Papers 46(3): 459-76.

Huguet, J. W. 2003. "International Migration and Development: Opportunities and Challenges for Poverty Reduction." In Selected Papers of the Fifth Asian and Pacific Population Conference. United Nations, New York, pp. 117-36.

Heckman, J. 1997. "Matching As an Econometric Evaluation Estimator: Evidence from Evaluating a Job Training Program.” Review of Economic Studies 64(4): 605-54.

Heckman, J., H. Ichimura, and P. Todd. 1998. "Matching As an Econometric Evaluation Estimator." Review of Economic Studies 65(2): 261-94.

Ichino, A., F. Mealli, and T. Nannicini. 2008. "From Temporary Help Jobs to Permanent Employment: What Can We Learn from Matching Estimators and Their Sensitivity?" Journal of Applied Econometrics 23(3): 305-27.

Koc, I. and I. Onan. 2004. "International Migrants' Remittances and Welfare Status of the Left behind Families in Turkey." International Migration Review 28(1): 78-112.

Lartey, E. K. K., F. S. Mandelman, and P. A. Acosta. 2012. "Remittances, Exchange Rate Regimes, and the Dutch Disease: A Panel Data Analysis." Review of International Economics 20(2): 377-95.

Lasagabaster, E., S. M. Maimbo, and S. Hulugalle. 2005. “Sri Lanka’s Migrant Labor 
Remittances: Enhancing the Quality and Outreach of the Rural Remittance Infrastructure.” Policy Research Working Paper No. 3789. Washington, DC: World Bank.

Lechner, M. 1999. "Identification and Estimation of Causal Effects of Multiple Treatments under the Conditional Independence Assumption." IZA Discussion Papers 91. Bonn, Germany: Institute for the Study of Labor (IZA).

Leuven, E. and B. Sianesi. 2003. "PSMATCH2: Stata Module to Perform Full Mahalanobis and Propensity Score Matching, Common Support Graphing, and Covariate Imbalance Testing." Statistical Software Components S432001. Boston, MA: Boston College Department of Economics, revised December 13, 2011.

Lim, L. L. and N. Oishi. 1996. "International Labor Migration of Asian Women: Distinctive Characteristics and Policy Concerns." Asian and Pacific Migration Journal 5(1): 85116.

Massey, D. S. and E. A. Parrado. 1998. "International Migration and Business Formation in Mexico.” Social Science Quarterly 79(1): 1-20.

McKenzie, D., J. Gibson, and S. Stillman. 2010. "How Important Is Selection? Experimental vs. Non-experimental Measures of the Income Gains from Migration." Journal of the European Economic Association 8(4): 913-45.

McKenzie, D. and H. Rapoport. 2010. "Self-selection Patterns in Mexico-U.S. Migration: The Role of Migration Networks." Review of Economics and Statistics 92(4): 811-21.

—. 2011. "Can Migration Reduce Educational Attainment? Evidence from Mexico." Journal of Population Economics 24(4): 1331-58.

McKenzie, D. and D. Yang. 2010. "Experimental Approaches in Migration Studies.” Policy Research Working Paper Series No. 5395. Washington, DC: World Bank Migration Policy Institute, MPI Data Hub. http://www.migrationinformation.org/datahub/remittances.cfm Accessed April 4, 2011.

Nguyen, T. and R. Purnamasari. 2011. "Impacts of International Migration and Remittances on Child Outcomes and Labor Supply in Indonesia: Does Gender Matter?" Policy Research Working Paper 5591. Washington, DC: World Bank.

Oishi, N. 2002. “Gender and Migration: An Integrative Approach.” Working Paper No. 49. San Diego, CA: Center for Comparative Immigration Studies at University of California, San Diego.

Poppe, R. 2010. "Expenditure Patterns of Migrant Households: Evidence from Moldova." Proceedings of the German Development Economics Conference, Hannover. No. 51. Verein für Socialpolitik, Research Committee Development Economics.

Rosenbaum, P. R. and D. B. Rubin. 1983. "The Central Role of the Propensity Score in Observational Studies for Causal Effects.” Biometrika 70: 41-55.

Sharma, M. and H. Zaman. 2009. "Who Migrates Overseas and Is It Worth Their While? An Assessment of Household Survey Data from Bangladesh.” Policy Research Working Paper 5018. Washington, DC: World Bank. 
Sri Lanka Bureau of Foreign Employment. 2009. Annual Statistical Report of Foreign Employment 2009.

Taylor, J. E., D. S. Massey, J. Arango, G. Hugo, A. Kouaouci, and A. Pellegrino. 1996. "International Migration and Community Development." Population Index 62(3): 397418.

Taylor, J. E. and J. Mora. 2006. "Does Migration Reshape Expenditures in Rural Households? Evidence from Mexico." Policy Research Paper 3842. Washington, DC: World Bank.

UNDP. 2009. HIV Vulnerabilities of Migrant Women: from Asia to the Arab States. Colombo, Sri Lanka: UNDP Regional Center.

Yang, D. 2008. "International Migration, Remittances, and Household Investment: Evidence from Philippine Migrants' Exchange Rate Shocks.” The Economic Journal 118: 591630.

— . 2011. "Migrant Remittances." Journal of Economic Perspectives 25(3): 129-52.

Yang, D. and C. A. Martinez. 2005. "Remittances and Poverty in Migrants' Home Areas: Evidence from the Philippines." In C. Ozden and M. Schiff (Eds.), International Migration, Remittances, and the Brain Drain. Washington, DC: World Bank.

Yeoh, B., S. Huang, and J. Gonzalez III. 1999. "Migrant Female Domestic Workers: Debating the Economic, Social and Political Impacts in Singapore." International Migration Review 33(1): 114-36. 
Table 1 Migration characteristics by gender of current migrants

\begin{tabular}{|c|c|c|c|}
\hline & & Females & Males \\
\hline Remittances (Annual) & & 41359 & 68327 \\
\hline \multicolumn{4}{|l|}{ Year of Migration } \\
\hline & 1995 & 0.02 & 0.04 \\
\hline & 1996 & 0.03 & 0.09 \\
\hline & 1997 & 0.20 & 0.10 \\
\hline & 1998 & 0.36 & 0.29 \\
\hline & 1999 & 0.30 & 0.30 \\
\hline & 2000 & 0.07 & 0.03 \\
\hline Duration $\leq 5$ years & & 0.98 & 0.85 \\
\hline \multicolumn{4}{|l|}{ Destination } \\
\hline Middle East & & 0.97 & 0.69 \\
\hline & Kuwait & 0.42 & 0.16 \\
\hline & Lebanon & 0.12 & 0.03 \\
\hline & Saudi Arabia & 0.23 & 0.26 \\
\hline & U.A.E. & 0.10 & 0.08 \\
\hline Europe & & 0.01 & 0.17 \\
\hline Americas & & 0.00 & 0.05 \\
\hline Observations & & 274 & 226 \\
\hline
\end{tabular}


Table 2 The matching of the migrant and nonmigrant households

\begin{tabular}{|c|c|c|c|c|c|c|c|c|c|c|c|c|c|}
\hline \multirow[b]{3}{*}{ Variable } & \multirow[b]{3}{*}{ Sample } & \multicolumn{6}{|c|}{ Current } & \multicolumn{6}{|c|}{ Return } \\
\hline & & \multicolumn{3}{|c|}{ Male } & \multicolumn{3}{|c|}{ Female } & \multicolumn{3}{|c|}{ Male } & \multicolumn{3}{|c|}{ Female } \\
\hline & & Treated & Control & p-value & Treated & Control & p-value & Treated & Control & p-value & Treated & Control & $\mathrm{p}$-value \\
\hline \multicolumn{14}{|l|}{$\begin{array}{l}\text { Household } \\
\text { demographics }\end{array}$} \\
\hline \multirow[t]{2}{*}{ No. women $17-30 \mathrm{yrs}$} & Unmatched & 0.882 & 0.601 & 0.000 & 1.000 & 0.600 & 0.000 & 0.636 & 0.599 & 0.425 & 0.690 & 0.599 & 0.014 \\
\hline & Matched & 0.816 & 0.753 & 0.471 & 0.943 & 0.821 & 0.096 & 0.618 & 0.623 & 0.945 & 0.674 & 0.649 & 0.661 \\
\hline \multirow[t]{2}{*}{ No. women $31-60$ yrs } & Unmatched & 0.953 & 0.825 & 0.000 & 1.004 & 0.825 & 0.000 & 0.897 & 0.827 & 0.034 & 0.973 & 0.827 & 0.000 \\
\hline & Matched & 0.930 & 0.900 & 0.563 & 0.967 & 0.925 & 0.405 & 0.896 & 0.861 & 0.463 & 0.938 & 0.905 & 0.348 \\
\hline \multirow[t]{2}{*}{ No. men 17-30 yrs } & Unmatched & 1.028 & 0.603 & 0.000 & 0.801 & 0.603 & 0.000 & 0.660 & 0.600 & 0.245 & 0.597 & 0.600 & 0.937 \\
\hline & Matched & 0.940 & 0.854 & 0.365 & 0.775 & 0.722 & 0.511 & 0.606 & 0.632 & 0.743 & 0.597 & 0.586 & 0.846 \\
\hline \multirow[t]{2}{*}{ No. men 31-60 yrs } & Unmatched & 0.953 & 0.756 & 0.000 & 0.668 & 0.752 & 0.012 & 0.881 & 0.756 & 0.000 & 0.796 & 0.756 & 0.133 \\
\hline & Matched & 0.920 & 0.856 & 0.247 & 0.672 & 0.707 & 0.485 & 0.871 & 0.817 & 0.244 & 0.793 & 0.776 & 0.642 \\
\hline \multirow[t]{2}{*}{ No. elderly } & Unmatched & 0.379 & 0.353 & 0.552 & 0.367 & 0.356 & 0.780 & 0.530 & 0.356 & 0.000 & 0.334 & 0.356 & 0.500 \\
\hline & Matched & 0.368 & 0.378 & 0.881 & 0.365 & 0.356 & 0.880 & 0.515 & 0.468 & 0.485 & 0.341 & 0.344 & 0.942 \\
\hline \multicolumn{14}{|l|}{ Household head } \\
\hline \multirow[t]{2}{*}{ Age } & Unmatched & 49.744 & 49.113 & 0.507 & 50.461 & 49.255 & 0.167 & 50.901 & 49.239 & 0.057 & 48.174 & 49.239 & 0.126 \\
\hline & Matched & 49.876 & 49.594 & 0.827 & 50.016 & 49.716 & 0.803 & 50.726 & 50.371 & 0.769 & 48.426 & 48.647 & 0.814 \\
\hline $\begin{array}{l}\text { Education - } \\
\text { Secondary (d) }\end{array}$ & Unmatched & 0.370 & 0.325 & 0.174 & 0.332 & 0.332 & 0.998 & 0.296 & 0.325 & 0.333 & 0.344 & 0.325 & 0.441 \\
\hline
\end{tabular}




\begin{tabular}{|c|c|c|c|c|c|c|c|c|c|c|c|c|c|}
\hline & Matched & 0.368 & 0.358 & 0.826 & 0.348 & 0.330 & 0.663 & 0.303 & 0.313 & 0.816 & 0.357 & 0.338 & 0.584 \\
\hline \multirow[t]{2}{*}{$\begin{array}{l}\text { Education - O Level } \\
\text { (d) }\end{array}$} & Unmatched & 0.289 & 0.144 & 0.000 & 0.055 & 0.144 & 0.000 & 0.269 & 0.142 & 0.000 & 0.155 & 0.142 & 0.476 \\
\hline & Matched & 0.284 & 0.241 & 0.337 & 0.057 & 0.088 & 0.195 & 0.261 & 0.217 & 0.254 & 0.152 & 0.156 & 0.896 \\
\hline \multirow[t]{2}{*}{$\begin{array}{l}\text { Education - A Level } \\
\text { (d) }\end{array}$} & Unmatched & 0.071 & 0.062 & 0.583 & 0.012 & 0.062 & 0.001 & 0.126 & 0.061 & 0.000 & 0.039 & 0.061 & 0.073 \\
\hline & Matched & 0.075 & 0.067 & 0.758 & 0.012 & 0.031 & 0.165 & 0.124 & 0.096 & 0.323 & 0.039 & 0.045 & 0.659 \\
\hline \multirow[t]{2}{*}{$\begin{array}{l}\text { Education - Tertiary } \\
\text { (d) }\end{array}$} & Unmatched & 0.024 & 0.020 & 0.695 & & & & 0.063 & 0.020 & 0.000 & 0.022 & 0.020 & 0.726 \\
\hline & Matched & 0.025 & 0.027 & 0.899 & & & & 0.054 & 0.045 & 0.663 & 0.021 & 0.023 & 0.850 \\
\hline \multicolumn{14}{|c|}{ Father's landownership status (default category-land owned) } \\
\hline \multirow[t]{2}{*}{ Landless (d) } & Unmatched & 0.758 & 0.652 & 0.001 & 0.723 & 0.642 & 0.008 & 0.739 & 0.641 & 0.001 & 0.759 & 0.641 & 0.000 \\
\hline & Matched & 0.756 & 0.715 & 0.354 & 0.721 & 0.691 & 0.462 & 0.730 & 0.704 & 0.531 & 0.749 & 0.722 & 0.389 \\
\hline \multirow[t]{2}{*}{$\begin{array}{l}\text { Land status unknown } \\
\text { (d) }\end{array}$} & Unmatched & & & & 0.020 & 0.018 & 0.835 & 0.016 & 0.018 & 0.834 & 0.025 & 0.018 & 0.304 \\
\hline & Matched & & & & 0.020 & 0.019 & 0.912 & 0.017 & 0.017 & 0.968 & 0.026 & 0.022 & 0.693 \\
\hline \multicolumn{14}{|c|}{ Father's education (default category - some schooling) } \\
\hline \multirow[t]{2}{*}{ No schooling $(\mathrm{d})$} & Unmatched & 0.062 & 0.175 & 0.000 & 0.180 & 0.178 & 0.942 & 0.079 & 0.174 & 0.000 & 0.123 & 0.174 & 0.008 \\
\hline & Matched & 0.065 & 0.101 & 0.191 & 0.172 & 0.171 & 0.976 & 0.083 & 0.118 & 0.199 & 0.124 & 0.135 & 0.637 \\
\hline \multirow[t]{2}{*}{ Schooling unknown (d) } & Unmatched & 0.190 & 0.178 & 0.654 & 0.191 & 0.187 & 0.860 & 0.186 & 0.185 & 0.971 & 0.256 & 0.185 & 0.000 \\
\hline & Matched & 0.184 & 0.179 & 0.890 & 0.184 & 0.186 & 0.973 & 0.187 & 0.189 & 0.948 & 0.251 & 0.223 & 0.368 \\
\hline
\end{tabular}


Mother's education (default category - some schooling)

\begin{tabular}{|c|c|c|c|c|c|c|c|c|c|c|c|c|c|}
\hline \multirow[t]{2}{*}{ No schooling (d) } & Unmatched & 0.147 & 0.258 & 0.000 & 0.293 & 0.260 & 0.242 & 0.142 & 0.257 & 0.000 & 0.211 & 0.257 & 0.042 \\
\hline & Matched & 0.144 & 0.178 & 0.358 & 0.287 & 0.279 & 0.840 & 0.145 & 0.190 & 0.188 & 0.202 & 0.219 & 0.560 \\
\hline \multirow[t]{2}{*}{ Schooling unknown (d) } & Unmatched & 0.190 & 0.185 & 0.860 & 0.199 & 0.194 & 0.833 & 0.186 & 0.192 & 0.817 & 0.256 & 0.192 & 0.002 \\
\hline & Matched & 0.189 & 0.181 & 0.828 & 0.189 & 0.192 & 0.911 & 0.183 & 0.188 & 0.879 & 0.256 & 0.226 & 0.338 \\
\hline \multicolumn{14}{|c|}{ Sector (default category - urban) } \\
\hline \multirow[t]{2}{*}{ Rural (d) } & Unmatched & 0.635 & 0.771 & 0.000 & 0.824 & 0.774 & 0.061 & 0.628 & 0.771 & 0.000 & 0.700 & 0.771 & 0.001 \\
\hline & Matched & 0.647 & 0.681 & 0.475 & 0.828 & 0.810 & 0.613 & 0.651 & 0.687 & 0.405 & 0.708 & 0.723 & 0.634 \\
\hline \multirow[t]{2}{*}{ Estate (plantation) (d) } & Unmatched & 0.014 & 0.050 & 0.018 & 0.020 & 0.050 & 0.025 & 0.036 & 0.050 & 0.311 & 0.042 & 0.050 & 0.479 \\
\hline & Matched & 0.015 & 0.027 & 0.413 & 0.020 & 0.031 & 0.454 & 0.037 & 0.044 & 0.725 & 0.044 & 0.046 & 0.888 \\
\hline \multicolumn{14}{|c|}{ Province (default - Western) } \\
\hline \multirow[t]{2}{*}{ Central } & Unmatched & 0.114 & 0.126 & 0.601 & 0.102 & 0.128 & 0.219 & 0.126 & 0.127 & 0.965 & 0.111 & 0.127 & 0.321 \\
\hline & Matched & 0.109 & 0.110 & 0.988 & 0.102 & 0.113 & 0.716 & 0.124 & 0.125 & 0.985 & 0.109 & 0.114 & 0.799 \\
\hline \multirow[t]{2}{*}{ Southern } & Unmatched & 0.104 & 0.121 & 0.473 & 0.109 & 0.120 & 0.620 & 0.154 & 0.121 & 0.111 & 0.204 & 0.121 & 0.000 \\
\hline & Matched & 0.100 & 0.102 & 0.924 & 0.107 & 0.111 & 0.886 & 0.162 & 0.142 & 0.547 & 0.199 & 0.179 & 0.482 \\
\hline \multirow[t]{2}{*}{ North and East } & Unmatched & 0.393 & 0.253 & 0.000 & 0.313 & 0.256 & 0.042 & 0.138 & 0.255 & 0.000 & 0.079 & 0.255 & 0.000 \\
\hline & Matched & 0.398 & 0.349 & 0.315 & 0.311 & 0.284 & 0.501 & 0.145 & 0.185 & 0.237 & 0.083 & 0.121 & 0.080 \\
\hline \multirow[t]{2}{*}{ North West } & Unmatched & 0.137 & 0.088 & 0.013 & 0.137 & 0.086 & 0.005 & 0.107 & 0.087 & 0.271 & 0.150 & 0.087 & 0.000 \\
\hline & Matched & 0.139 & 0.121 & 0.590 & 0.135 & 0.117 & 0.556 & 0.104 & 0.098 & 0.829 & 0.134 & 0.130 & 0.859 \\
\hline North Central & Unmatched & 0.019 & 0.067 & 0.006 & 0.113 & 0.068 & 0.006 & 0.024 & 0.068 & 0.006 & 0.103 & 0.068 & 0.006 \\
\hline
\end{tabular}




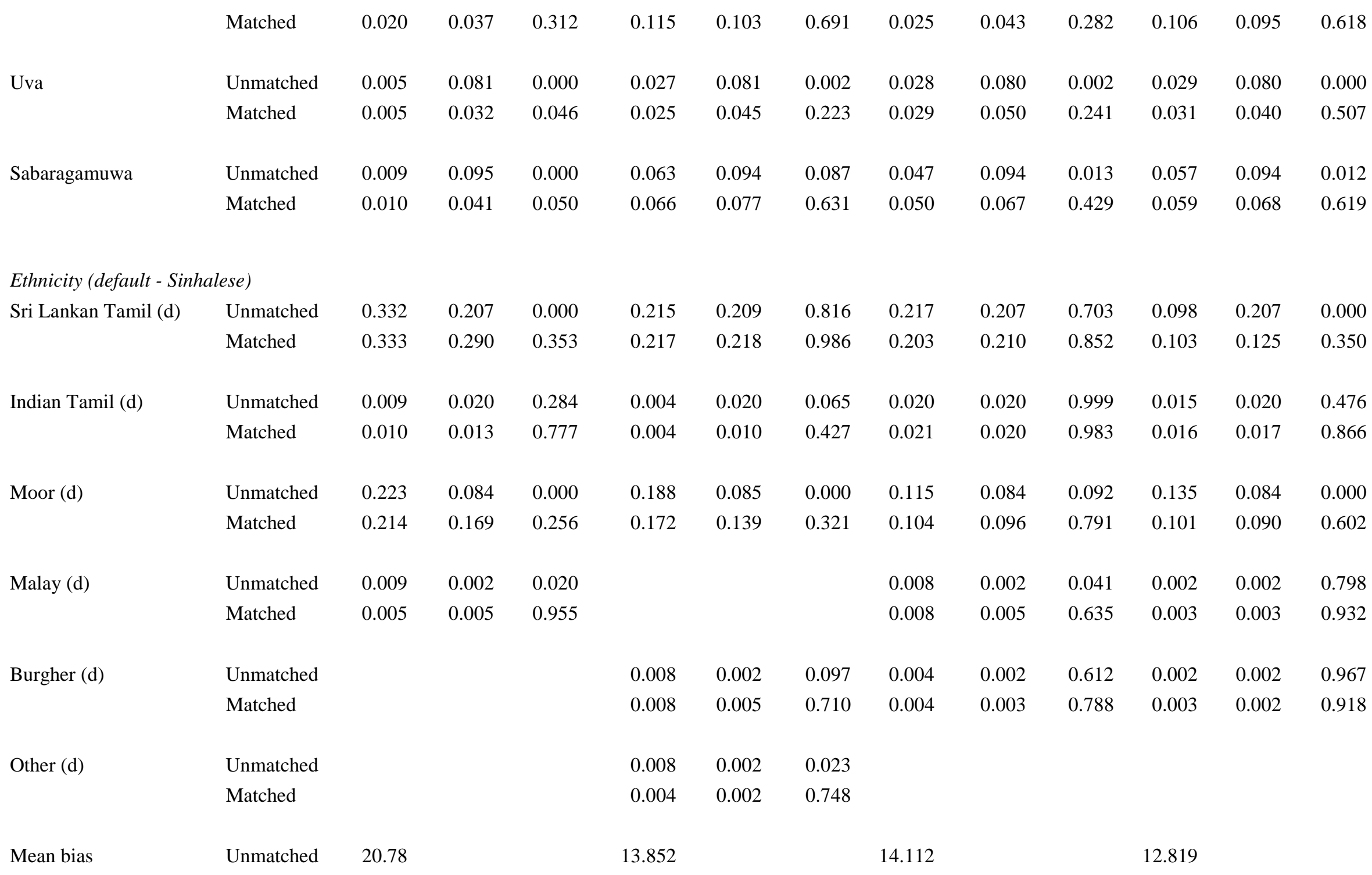




\begin{tabular}{|c|c|c|c|c|c|}
\hline & & (14.2) & (12.01) & (10.81) & (10.93) \\
\hline & Matched & 6.4169 & 4.814 & 5.1089 & 3.419 \\
\hline & & $(4.41)$ & ( 3.64$)$ & (3.776) & (2.349) \\
\hline \multirow[t]{2}{*}{ Pseudo R2 } & Unmatched & 0.171 & 0.106 & 0.113 & 0.084 \\
\hline & Matched & 0.035 & 0.020 & 0.023 & 0.009 \\
\hline \multirow[t]{2}{*}{ LR Chi2 } & Unmatched & 317.18 & 227.97 & 241.94 & 257.96 \\
\hline & Matched & 19.59 & 13.26 & 15.19 & 9.99 \\
\hline \multirow[t]{2}{*}{ p> Chi2 } & Unmatched & 0.000 & 0.000 & 0.000 & 0.000 \\
\hline & Matched & 0.879 & 0.995 & 0.989 & 1.000 \\
\hline
\end{tabular}


Table 3 PSM estimates

a) Females

\begin{tabular}{|c|c|c|c|c|c|c|}
\hline \multirow{3}{*}{ Obs } & \multicolumn{4}{|c|}{ Differences } & \multicolumn{2}{|c|}{ Difference in Difference } \\
\hline & \multicolumn{2}{|c|}{$\begin{array}{c}\text { Current } \\
6501\end{array}$} & \multicolumn{2}{|c|}{$\begin{array}{c}\text { Return } \\
6779\end{array}$} & \multirow[b]{2}{*}{ Unmatched } & \multirow[b]{2}{*}{ Matched } \\
\hline & Unmatched & Matched & Unmatched & Matched & & \\
\hline \multirow[t]{2}{*}{ Variable } & $\mathrm{b}$ & $\mathrm{b}$ & $\mathrm{b}$ & $\mathrm{b}$ & $\mathrm{b}$ & $\mathrm{b}$ \\
\hline & se & se & se & se & se & se \\
\hline \multirow[t]{2}{*}{ Income p.c. (Rs) } & -616.67 & -94.69 & -412.50 & -215.59 & 204.17 & -120.90 \\
\hline & 2978.24 & 288.09 & 2340.54 & 467.63 & 3787.89 & 549.25 \\
\hline \multirow[t]{2}{*}{ Expenditure p.c. (Rs) } & $-548.45^{* *}$ & $-410.71 * *$ & $272.96 * *$ & $315.89 * *$ & $821.42 * *$ & $726.59 * *$ \\
\hline & 99.55 & 46.98 & 86.95 & 126.53 & 132.17 & 134.97 \\
\hline \multirow[t]{2}{*}{ Value of durables (Rs) } & $-26576.77 * *$ & $-20184.34 * *$ & 16036.27 & 8664.25 & $42613.04 * *$ & $28848.59 * *$ \\
\hline & 11298.85 & 4464.05 & 10205.89 & 11248.51 & 15225.78 & 12101.93 \\
\hline \multirow[t]{2}{*}{ Adult good expenditure share } & $0.0638 * *$ & $0.0713 * *$ & 0.0120 & 0.0229 & $-0.0518 * *$ & $-0.0483 * *$ \\
\hline & 0.0157 & 0.0185 & 0.0124 & 0.0139 & 0.0200 & 0.0231 \\
\hline \multirow[t]{2}{*}{ Schooling expenditure share } & -0.0035 & -0.0021 & 0.0021 & -0.0004 & $0.0056^{*}$ & 0.0017 \\
\hline & 0.0025 & 0.0023 & 0.0021 & 0.0021 & 0.0033 & 0.0031 \\
\hline \multirow[t]{2}{*}{ Homeownership (d) } & $0.0476^{*}$ & $0.0501 * *$ & -0.0193 & -0.0019 & $-0.0670 *$ & -0.0520 \\
\hline & 0.0268 & 0.0244 & 0.0215 & 0.0226 & 0.0344 & 0.0333 \\
\hline
\end{tabular}




\begin{tabular}{|c|c|c|c|c|c|c|}
\hline \multirow[t]{2}{*}{ Home value (Rs) } & -170843.30 & $-95975.33 * *$ & $232283.38^{*}$ & 199160.70 & $403126.68 * *$ & 295136.03 \\
\hline & 151383.12 & 32596.04 & 130987.47 & 194469.80 & 200186.33 & 197182.67 \\
\hline \multirow[t]{2}{*}{ Modern wall (d) } & 0.0273 & 0.0404 & $0.0832 * *$ & $0.0691 * *$ & $0.0559 *$ & 0.0287 \\
\hline & 0.0265 & 0.0267 & 0.0209 & 0.0179 & 0.0337 & 0.0322 \\
\hline \multirow[t]{2}{*}{ Modern floor (d) } & -0.0029 & -0.0034 & $0.0926^{* *}$ & $0.0699 * *$ & $0.0955^{* *}$ & $0.0733 * *$ \\
\hline & 0.0278 & 0.0275 & 0.0219 & 0.0189 & 0.0354 & 0.0333 \\
\hline \multirow[t]{2}{*}{ Modern roof (d) } & 0.0263 & 0.0362 & $0.0614 * *$ & $0.0390 * *$ & 0.0350 & 0.0029 \\
\hline & 0.0286 & 0.0283 & 0.0227 & 0.0204 & 0.0365 & 0.0349 \\
\hline \multirow[t]{2}{*}{ Tap water (d) } & $-0.0365^{*}$ & -0.0219 & $0.0477 * *$ & 0.0186 & $0.0842 * *$ & 0.0405 \\
\hline & 0.0211 & 0.0178 & 0.0174 & 0.0183 & 0.0274 & 0.0256 \\
\hline \multirow{2}{*}{ Electric lighting (d) } & 0.0150 & 0.0334 & $0.1372 * *$ & $0.0766^{* *}$ & $0.1222 * *$ & 0.0432 \\
\hline & 0.0317 & 0.0320 & 0.0253 & 0.0227 & 0.0405 & 0.0392 \\
\hline \multirow[t]{2}{*}{ Flush toilet (d) } & 0.0171 & 0.0437 & 0.0118 & -0.0121 & -0.0052 & $-0.0558^{*}$ \\
\hline & 0.0249 & 0.0243 & 0.0199 & 0.0200 & 0.0319 & 0.0315 \\
\hline \multirow[t]{2}{*}{ Gas or electric stove (d) } & $-0.0622 * *$ & $-0.0359 * *$ & $0.0888 * *$ & $0.0553 * *$ & $0.1509 * *$ & $0.0912 * *$ \\
\hline & 0.0225 & 0.0176 & 0.0188 & 0.0199 & 0.0293 & 0.0266 \\
\hline \multirow[t]{2}{*}{ Farm land (ha) } & $-0.3458 * *$ & $-0.3576 * *$ & $-0.2023 * *$ & -0.0673 & 0.1435 & $0.2902 * *$ \\
\hline & 0.1072 & 0.0581 & 0.0857 & 0.0599 & 0.1373 & 0.0834 \\
\hline Farm assets value (Rs) & -1011.80 & -1134.84 & -3222.42 & -1446.47 & -2210.62 & -311.63 \\
\hline
\end{tabular}




\begin{tabular}{|c|c|c|c|c|c|c|}
\hline & 3051.15 & 4160.58 & 2325.33 & 1093.48 & 3836.24 & 4301.87 \\
\hline \multirow[t]{2}{*}{ Nonfarm assets value (Rs) } & -11003.59 & -9241.21 & $39687.77 * *$ & 35761.84 & $50691.37 * *$ & $45003.05^{*}$ \\
\hline & 11289.31 & 5692.13 & 13734.68 & 26615.10 & 17778.92 & 27216.98 \\
\hline \multirow[t]{2}{*}{ Net debt (Rs) } & -10244.76 & $-6780.42 * *$ & -184.37 & 889.49 & 10060.39 & 7669.90 \\
\hline & 6885.17 & 2222.88 & 7078.19 & 5483.25 & 9874.53 & 5916.69 \\
\hline \multirow[t]{2}{*}{ Business owned (d) } & -0.0218 & -0.0367 & $0.0301 *$ & 0.0041 & $0.0519 *$ & 0.0408 \\
\hline & 0.0228 & 0.0230 & 0.0183 & 0.0202 & 0.0292 & 0.0306 \\
\hline \multirow[t]{2}{*}{ Self-financed business (d) } & -0.0305 & -0.0409 & 0.0224 & 0.0004 & $0.0529 * *$ & 0.0413 \\
\hline & 0.0204 & 0.0188 & 0.0164 & 0.0184 & 0.0261 & 0.0263 \\
\hline
\end{tabular}

\section{b) Males}

Obs

Variable

Income p.c. (Rs)

Expenditure p.c. (Rs)

$\begin{array}{ccc} & \text { Differences } & \\ \text { Current } & & \text { Return } \\ 6456 & 6625\end{array}$

Unmatched

b

se

663.11

3288.10

33.27
Matched

b

se

837.70
1095.26

$-97.46$
Unmatched

Matched

b

se

se

2999.35

2979.02

1769.10**

1163.44

$1058.48 * *$

$785.54 * *$

\section{Differences in Differences}

Unmatched Matched

$\begin{array}{cc}\mathrm{b} & \mathrm{b} \\ \mathrm{se} & \mathrm{se}\end{array}$

$2336.25 \quad 931.39$

$4436.91 \quad 1597.86$

$1025.21 * * \quad 882.99 * *$ 


\begin{tabular}{|c|c|c|c|c|c|c|}
\hline & 110.70 & 78.80 & 108.34 & 159.39 & 154.90 & 177.80 \\
\hline \multirow[t]{2}{*}{ Value of durables (Rs) } & $25874.50 *$ & 2909.83 & $220715.20 * *$ & $180962.1 * *$ & $194840.70 * *$ & $178052.27 * *$ \\
\hline & 13874.45 & 11389.92 & 18959.27 & 67432.78 & 23493.70 & 68387.94 \\
\hline \multirow[t]{2}{*}{ Adult good expenditure share } & $-0.0963 * *$ & $-0.0811 * *$ & $-0.0387 * *$ & -0.0181 & $0.0576^{* *}$ & $0.0629 * *$ \\
\hline & 0.0168 & 0.0109 & 0.0154 & 0.0131 & 0.0228 & 0.0170 \\
\hline \multirow[t]{2}{*}{ Schooling expenditure share } & 0.0038 & 0.0035 & 0.0012 & -0.0002 & -0.0026 & -0.0037 \\
\hline & 0.0028 & 0.0029 & 0.0026 & 0.0024 & 0.0038 & 0.0038 \\
\hline \multirow[t]{2}{*}{ Homeownership (d) } & -0.0130 & -0.0200 & 0.0312 & $0.0453 * *$ & 0.0442 & $0.0653 *$ \\
\hline & 0.0294 & 0.0317 & 0.0269 & 0.0245 & 0.0399 & 0.0400 \\
\hline \multirow[t]{2}{*}{ Home value (Rs) } & 185561.79 & 51518.42 & $1470484.5^{* *}$ & $1197527 * *$ & $1284922.7 * *$ & $1146008.5^{* *}$ \\
\hline & 173278.11 & 90868.03 & 179351.69 & 463850.2 & 249383.90 & 472666.91 \\
\hline \multirow[t]{2}{*}{ Modern wall (d) } & $0.1653 * *$ & $0.1218^{* *}$ & $0.1155^{* *}$ & $0.0602 * *$ & -0.0498 & $-0.0616^{* *}$ \\
\hline & 0.0285 & 0.0169 & 0.0263 & 0.0205 & 0.0388 & 0.0266 \\
\hline \multirow[t]{2}{*}{ Modern floor (d) } & $0.2210 * *$ & $0.1436^{* *}$ & $0.1392 * *$ & $0.0648 * *$ & $-0.0819 * *$ & $-0.0788 * *$ \\
\hline & 0.0299 & 0.0158 & 0.0275 & 0.0208 & 0.0406 & 0.0261 \\
\hline \multirow[t]{2}{*}{ Modern roof (d) } & $0.1169 * *$ & $0.0825^{* *}$ & $0.1170 * *$ & $0.0698 * *$ & 0.0001 & -0.0127 \\
\hline & 0.0310 & 0.0268 & 0.0284 & 0.0238 & 0.0421 & 0.0359 \\
\hline \multirow[t]{2}{*}{ Tap water (d) } & $0.1616^{* *} *$ & $0.1093 * *$ & $0.2083^{* *}$ & $0.1330 * *$ & 0.0467 & 0.0237 \\
\hline & 0.0240 & 0.0294 & 0.0221 & 0.0267 & 0.0326 & 0.0397 \\
\hline
\end{tabular}




\begin{tabular}{|c|c|c|c|c|c|c|}
\hline Electric lighting (d) & $\begin{array}{c}0.2098 * * \\
0.0346\end{array}$ & $\begin{array}{c}0.1236 * * \\
0.0292\end{array}$ & $\begin{array}{c}0.2062 * * \\
0.0317\end{array}$ & $\begin{array}{c}0.1006 * * \\
0.0252\end{array}$ & $\begin{array}{l}-0.0036 \\
0.0469\end{array}$ & $\begin{array}{l}-0.0229 \\
0.0386\end{array}$ \\
\hline Flush toilet (d) & $\begin{array}{l}0.0330 \\
0.0271\end{array}$ & $\begin{array}{l}0.0360 \\
0.0274\end{array}$ & $\begin{array}{c}0.0519 * * \\
0.0249\end{array}$ & $\begin{array}{l}0.0182 \\
0.0223\end{array}$ & $\begin{array}{l}0.0189 \\
0.0368\end{array}$ & $\begin{array}{l}-0.0179 \\
0.0353\end{array}$ \\
\hline Gas or electric stove (d) & $\begin{array}{c}0.1734 * * \\
0.0258\end{array}$ & $\begin{array}{c}0.1141 * * \\
0.0318\end{array}$ & $\begin{array}{c}0.3055^{* *} \\
0.0237\end{array}$ & $\begin{array}{c}0.1880^{* *} \\
0.0263\end{array}$ & $\begin{array}{c}0.1321 * * \\
0.0351\end{array}$ & $\begin{array}{c}0.0739 * \\
0.0412\end{array}$ \\
\hline Farm land (ha) & $\begin{array}{c}-0.3458 * * \\
0.1183\end{array}$ & $\begin{array}{c}-0.3567 * * \\
0.0920\end{array}$ & $\begin{array}{c}-0.3450 * * \\
0.1081\end{array}$ & $\begin{array}{c}-0.1964 * * \\
0.0789\end{array}$ & $\begin{array}{l}0.0008 \\
0.1603\end{array}$ & $\begin{array}{l}0.1603 \\
0.1211\end{array}$ \\
\hline Farm assets value (Rs) & $\begin{array}{c}-3511.58 \\
3131.63\end{array}$ & $\begin{array}{c}-6547.28 \\
3148.16\end{array}$ & $\begin{array}{l}-2899.19 \\
2959.26\end{array}$ & $\begin{array}{c}-1750.56 \\
2183.69\end{array}$ & $\begin{array}{c}612.38 \\
4308.63\end{array}$ & $\begin{array}{l}4796.72 \\
3831.37\end{array}$ \\
\hline Nonfarm assets value (Rs) & $\begin{array}{c}61260.02 * * \\
17551.17\end{array}$ & $\begin{array}{c}44387.38 * * \\
20666.21\end{array}$ & $\begin{array}{c}162410.10 * * \\
19020.86\end{array}$ & $\begin{array}{c}133892.8 * * \\
53647.77\end{array}$ & $\begin{array}{c}101150.07 * * \\
25881.20\end{array}$ & $\begin{array}{l}89505.42 \\
57490.66\end{array}$ \\
\hline Net debt (Rs) & $\begin{array}{c}22763.48^{* *} \\
10479.23\end{array}$ & $\begin{array}{l}21126.09 \\
18906.93\end{array}$ & $\begin{array}{c}54513.21 * * \\
10045.97\end{array}$ & $\begin{array}{c}38600.73^{* *} \\
20271.87\end{array}$ & $\begin{array}{c}31749.73 * * \\
14516.74\end{array}$ & $\begin{array}{l}17474.64 \\
27720.40\end{array}$ \\
\hline Business owned (d) & $\begin{array}{c}-0.0271 \\
0.0250\end{array}$ & $\begin{array}{r}-0.0562 \\
0.0245\end{array}$ & $\begin{array}{c}0.1274 * * \\
0.0231\end{array}$ & $\begin{array}{c}0.1040 * * \\
0.0290\end{array}$ & $\begin{array}{c}0.1546^{* *} \\
0.0340\end{array}$ & $\begin{array}{c}0.1601 * * \\
0.0380\end{array}$ \\
\hline Self-financed business (d) & $\begin{array}{c}-0.0306 \\
0.0223\end{array}$ & $\begin{array}{c}-0.0524 * * \\
0.0210\end{array}$ & $\begin{array}{c}0.1141^{* *} \\
0.0208\end{array}$ & $\begin{array}{c}0.0952 * * \\
0.0278\end{array}$ & $\begin{array}{c}0.1447 * * \\
0.0305\end{array}$ & $\begin{array}{c}0.1475^{* *} \\
0.0349\end{array}$ \\
\hline
\end{tabular}




\section{APPENDIX}

Table Al Descriptive statistics of dependent variables

\begin{tabular}{|c|c|c|c|c|c|c|c|c|c|c|}
\hline \multirow{3}{*}{ Income and Expenditure } & \multirow{2}{*}{\multicolumn{2}{|c|}{ Nonmigrant }} & \multicolumn{4}{|c|}{ Current Migrant } & \multicolumn{4}{|c|}{ Return Migrant } \\
\hline & & & \multicolumn{2}{|c|}{ Male } & \multicolumn{2}{|c|}{ Female } & \multicolumn{2}{|c|}{ Male } & \multicolumn{2}{|c|}{ Female } \\
\hline & & & & & & & & & & \\
\hline Income p.c. (Rs) & 2591 & 46875 & 3308 & 16281 & 1932 & 2395 & 5534 & 21342 & 2160 & 6415 \\
\hline Expenditure p.c. (Rs) & 1994 & 1630 & 2036 & 979 & 1413 & 629 & 3057 & 2785 & 2256 & 2545 \\
\hline Value of durables (Rs) & 74376 & 200972 & 100081 & 138663 & 43604 & 63020 & 292082 & 1134119 & 89198 & 219921 \\
\hline Schooling expenditure share & 0.031 & 0.040 & 0.035 & 0.042 & 0.027 & 0.035 & 0.032 & 0.037 & 0.033 & 0.039 \\
\hline Adult good expenditure share & 0.154 & 0.242 & 0.058 & 0.138 & 0.219 & 0.295 & 0.115 & 0.201 & 0.165 & 0.250 \\
\hline \multicolumn{11}{|l|}{ Housing } \\
\hline Homeownership (d) & 0.772 & 0.420 & 0.758 & 0.429 & 0.816 & 0.388 & 0.802 & 0.400 & 0.749 & 0.434 \\
\hline Home value (Rs) & 424119 & 2473318 & 613972 & 1135438 & 227614 & 419097 & 1887933 & 7040104 & 653980 & 3562872 \\
\hline Modern wall (d) & 0.782 & 0.413 & 0.940 & 0.239 & 0.803 & 0.398 & 0.891 & 0.312 & 0.859 & 0.349 \\
\hline Modern roof (d) & 0.725 & 0.446 & 0.842 & 0.366 & 0.749 & 0.434 & 0.840 & 0.367 & 0.785 & 0.411 \\
\hline Modern floor (d) & 0.750 & 0.433 & 0.967 & 0.178 & 0.745 & 0.437 & 0.883 & 0.322 & 0.839 & 0.368 \\
\hline Tap water (d) & 0.132 & 0.339 & 0.293 & 0.456 & 0.088 & 0.285 & 0.335 & 0.473 & 0.178 & 0.383 \\
\hline Flush toilet (d) & 0.813 & 0.390 & 0.847 & 0.361 & 0.827 & 0.379 & 0.856 & 0.352 & 0.824 & 0.381 \\
\hline Electric lighting (d) & 0.560 & 0.496 & 0.772 & 0.420 & 0.569 & 0.496 & 0.759 & 0.429 & 0.693 & 0.462 \\
\hline Gas or electric stove (d) & 0.157 & 0.364 & 0.335 & 0.473 & 0.085 & 0.279 & 0.459 & 0.499 & 0.244 & 0.430 \\
\hline \multicolumn{11}{|l|}{ Assets and business } \\
\hline Farm land (ha) & 0.633 & 1.711 & 0.284 & 1.118 & 0.287 & 0.745 & 0.283 & 1.143 & 0.428 & 1.128 \\
\hline Farm assets value (Rs) & 6542 & 47065 & 2817 & 29803 & 5400 & 64176 & 3555 & 31463 & 3245 & 19710 \\
\hline
\end{tabular}




$\begin{array}{lrrrrrrrrrr}\text { Nonfarm assets value (Rs) } & 51879 & 248453 & 111695 & 274666 & 34924 & 68708 & 212287 & 870143 & 90779 & 492608 \\ \text { Net debt (Rs) } & 14117 & 140181 & 36570 & 293060 & 4340 & 22561 & 67821 & 377073 & 13859 & 92469 \\ \text { Business owned (d) } & 0.151 & 0.358 & 0.121 & 0.327 & 0.126 & 0.333 & 0.272 & 0.446 & 0.178 & 0.383 \\ \text { Self-financed business (d) } & 0.116 & 0.321 & 0.084 & 0.278 & 0.084 & 0.278 & 0.226 & 0.419 & 0.137 & 0.344\end{array}$

Note: Rs - Rupees; ha - hecrares; d - dummy variable 
Table A2 Descriptive statistics of independent variables

\begin{tabular}{|c|c|c|c|c|c|c|c|c|c|c|}
\hline \multirow{3}{*}{ Household demographics } & \multirow{2}{*}{\multicolumn{2}{|c|}{ Nonmigrant }} & \multicolumn{4}{|c|}{ Current Migrant } & \multicolumn{4}{|c|}{ Return Migrant } \\
\hline & & & \multicolumn{2}{|c|}{ Male } & \multicolumn{2}{|c|}{ Female } & \multicolumn{2}{|c|}{ Male } & \multicolumn{2}{|c|}{ Female } \\
\hline & & & & & & & & & & \\
\hline No. children $0-6$ yrs & 0.421 & 0.699 & 0.484 & 0.748 & 0.322 & 0.671 & 0.440 & 0.665 & 0.454 & 0.706 \\
\hline No. children $7-16$ yrs & 0.917 & 1.119 & 0.884 & 0.991 & 1.015 & 1.153 & 0.868 & 0.955 & 0.980 & 1.053 \\
\hline No. women 17-30 yrs & 0.601 & 0.723 & 0.870 & 0.968 & 1.004 & 0.830 & 0.638 & 0.794 & 0.693 & 0.832 \\
\hline No. women 31-60 yrs & 0.827 & 0.519 & 0.953 & 0.545 & 1.008 & 0.626 & 0.895 & 0.545 & 0.973 & 0.530 \\
\hline No. men $17-30$ yrs & 0.599 & 0.799 & 1.019 & 1.050 & 0.801 & 0.919 & 0.661 & 0.909 & 0.595 & 0.741 \\
\hline No. men 31-60 yrs & 0.756 & 0.527 & 0.949 & 0.590 & 0.670 & 0.554 & 0.879 & 0.505 & 0.793 & 0.512 \\
\hline \multicolumn{11}{|l|}{ Household head } \\
\hline Age & 49.3 & 13.7 & 49.6 & 13.0 & 50.3 & 13.2 & 50.9 & 12.6 & 48.2 & 13.0 \\
\hline Education - Secondary (d) & 0.325 & 0.468 & 0.372 & 0.484 & 0.330 & 0.471 & 0.300 & 0.459 & 0.341 & 0.475 \\
\hline Education - O Level (d) & 0.141 & 0.348 & 0.288 & 0.454 & 0.057 & 0.233 & 0.265 & 0.442 & 0.154 & 0.361 \\
\hline Education - A Level (d) & 0.061 & 0.240 & 0.070 & 0.255 & 0.011 & 0.107 & 0.128 & 0.335 & 0.039 & 0.194 \\
\hline Education - Tertiary (d) & 0.020 & 0.139 & 0.023 & 0.151 & 0.000 & 0.000 & 0.062 & 0.242 & 0.022 & 0.147 \\
\hline \multicolumn{11}{|c|}{ Father's landownership status (default category-land owned) } \\
\hline Landless (d) & 0.641 & 0.480 & 0.763 & 0.426 & 0.728 & 0.446 & 0.739 & 0.440 & 0.759 & 0.428 \\
\hline Land status unknown (d) & 0.018 & 0.132 & 0.000 & 0.000 & 0.019 & 0.137 & 0.016 & 0.124 & 0.027 & 0.162 \\
\hline \multicolumn{11}{|c|}{ Father's education (default category - some schooling) } \\
\hline No schooling (d) & 0.175 & 0.380 & 0.060 & 0.239 & 0.185 & 0.389 & 0.078 & 0.268 & 0.122 & 0.328 \\
\hline Schooling unknown (d) & 0.186 & 0.389 & 0.195 & 0.397 & 0.192 & 0.395 & 0.187 & 0.390 & 0.261 & 0.440 \\
\hline
\end{tabular}

Mother's education (default category - some schooling) 
No schooling (d)

Schooling unknown (d)

Sector (default category - urban)

Rural (d)

Estate (plantation) (d)

Province (default - Western)

\section{Central}

Southern

North and East

North West

North Central

Uva

Sabaragamuwa

Ethnicity (default - Sinhalese) Sri Lankan Tamil (d)

Indian Tamil (d)

Moor (d)

Malay (d)

Burgher (d)

Other (d) $\begin{array}{lll}0.257 & 0.437 & 0.145\end{array}$

$\begin{array}{lll}0.193 & 0.394 & 0.196\end{array}$

0.353

0.295

0.457

0.140

0.187

0.348

0.215

0.411

0.199

$\begin{array}{lll}0.771 & 0.420 & 0.637\end{array}$

$\begin{array}{llll}0.049 & 0.217 & 0.014\end{array}$

0.482

0.828

0.118

0.019

0.378

0.137

0.630

0.484

0.184

0.702

0.041

0.458
0.200

$\begin{array}{lll}0.128 & 0.334 & 0.112\end{array}$

0.316

0.100

0.300

0.125

0.331

0.110

0.313

$\begin{array}{lll}0.120 & 0.325 & 0.102\end{array}$

0.304

0.107

0.310

0.152

0.359

0.202

0.402

$\begin{array}{llll}0.255 & 0.436 & 0.391\end{array}$

0.347

0.138

0.465

0.148

0.356

0.080

0.272

$\begin{array}{llll}0.068 & 0.251 & 0.019\end{array}$

0.135

0.111

0.105

0.307

0.151

0.359

$\begin{array}{llll}0.080 & 0.271 & 0.005\end{array}$

0.068

0.027

0.162

0.023

0.151

0.102

0.304

$\begin{array}{lll}0.094 & 0.292 & 0.009\end{array}$

0.096

0.065

0.247

0.047

0.163

0.029

0.169

$0.059 \quad 0.235$

$\begin{array}{llllllllll}0.207 & 0.405 & 0.335 & 0.473 & 0.215 & 0.411 & 0.226 & 0.419 & 0.100 & 0.300 \\ 0.020 & 0.139 & 0.009 & 0.096 & 0.004 & 0.062 & 0.019 & 0.138 & 0.015 & 0.120 \\ 0.084 & 0.278 & 0.219 & 0.414 & 0.188 & 0.391 & 0.113 & 0.317 & 0.134 & 0.341 \\ 0.002 & 0.043 & 0.009 & 0.096 & 0.000 & 0.000 & 0.008 & 0.088 & 0.002 & 0.049 \\ 0.002 & 0.050 & 0.000 & 0.000 & 0.008 & 0.087 & 0.004 & 0.062 & 0.002 & 0.049 \\ 0.002 & 0.039 & 0.005 & 0.068 & 0.008 & 0.087 & 0.000 & 0.000 & 0.000 & 0.000\end{array}$


Table A3 Probit estimates for migration

Number of obs
LR chi2(30)
Prob > chi2
Log likelihood
Pseudo R2

Pseudo R2

\begin{tabular}{|c|c|c|c|c|c|c|c|c|c|c|c|}
\hline \multicolumn{6}{|c|}{ Current Migrant } & \multicolumn{6}{|c|}{ Return Migrant } \\
\hline & Male & & & Fema & & & Male & & & Fema & \\
\hline & & 6456 & & & 6501 & & & 6625 & & & 6779 \\
\hline & & 317.18 & & & 227.97 & & & 241.94 & & & 257.96 \\
\hline & & 0 & & & 0 & & & 0 & & & 0 \\
\hline & & -770.73 & & & -964.9 & & & -953.24 & & & -1410.3 \\
\hline & & 0.1707 & & & 0.1056 & & & 0.1126 & & & 0.0838 \\
\hline Coef. & & Std. Err. & Coef. & & Std. Err. & Coef. & & Std. Err. & Coef. & & Std. Err. \\
\hline 0.145 & $* * *$ & 0.042 & 0.286 & $* * *$ & 0.037 & 0.045 & & 0.041 & 0.125 & $* * *$ & 0.034 \\
\hline 0.119 & $*$ & 0.069 & 0.379 & $* * *$ & 0.058 & 0.049 & & 0.061 & 0.310 & $* * *$ & 0.051 \\
\hline 0.260 & $* * *$ & 0.038 & 0.034 & & 0.037 & 0.070 & $*$ & 0.038 & -0.046 & & 0.034 \\
\hline 0.378 & $* * *$ & 0.065 & -0.131 & $* *$ & 0.059 & 0.222 & $* * *$ & 0.059 & -0.006 & & 0.051 \\
\hline 0.197 & $* * *$ & 0.064 & 0.093 & & 0.062 & 0.244 & $* * *$ & 0.054 & 0.091 & $*$ & 0.053 \\
\hline 0.000 & & 0.003 & -0.004 & & 0.003 & 0.000 & & 0.003 & -0.010 & $* * *$ & 0.003 \\
\hline 0.282 & $* * *$ & 0.089 & -0.157 & $* *$ & 0.070 & 0.210 & $* * *$ & 0.082 & -0.024 & & 0.062 \\
\hline 0.510 & $* * *$ & 0.099 & -0.608 & $* * *$ & 0.121 & 0.516 & $* * *$ & 0.092 & -0.023 & & 0.081 \\
\hline 0.284 & $*$ & 0.148 & -0.820 & $* * *$ & 0.225 & 0.557 & $* * *$ & 0.120 & -0.280 & $* *$ & 0.132 \\
\hline 0.398 & $* *$ & 0.220 & & & & 0.759 & $* * *$ & 0.163 & 0.027 & & 0.179 \\
\hline
\end{tabular}


Father's landownership status (default category-land owned)

\begin{tabular}{|c|c|c|c|c|c|c|c|c|c|c|c|c|}
\hline \multirow[t]{2}{*}{ Landless (d) } & \multicolumn{2}{|l|}{0.114} & \multirow[t]{2}{*}{0.081} & 0.129 & \multirow[t]{2}{*}{$*$} & 0.071 & 0.136 & \multirow[t]{2}{*}{$*$} & \multirow{2}{*}{$\begin{array}{l}0.074 \\
0.240\end{array}$} & \multirow{2}{*}{$\begin{array}{l}0.213 \\
0.331\end{array}$} & \multirow{2}{*}{$\begin{array}{l}* * * \\
*\end{array}$} & \multirow{2}{*}{$\begin{array}{l}0.062 \\
0.182\end{array}$} \\
\hline & wn $(d)$ & & & 0.097 & & 0.229 & 0.243 & & & & & \\
\hline \multicolumn{13}{|c|}{ Father's education (default category - some schooling) } \\
\hline No schooling (d) & -0.424 & $* * *$ & 0.152 & -0.166 & $*$ & 0.100 & -0.145 & & 0.122 & -0.052 & & 0.089 \\
\hline Schooling unknown (d) & 0.015 & & 0.133 & -0.097 & & 0.111 & 0.043 & & 0.117 & 0.062 & & 0.091 \\
\hline \multicolumn{13}{|c|}{ Mother's education (default category - some schooling) } \\
\hline No schooling (d) & 0.010 & & 0.117 & 0.067 & & 0.087 & -0.099 & & 0.102 & -0.023 & & 0.076 \\
\hline Schooling unknown (d) & 0.001 & & 0.135 & -0.014 & & 0.112 & -0.077 & & 0.119 & 0.059 & & 0.093 \\
\hline \multicolumn{13}{|c|}{ Sector (default category - urban) } \\
\hline Rural (d) & -0.283 & $* * *$ & 0.088 & 0.131 & & 0.092 & -0.022 & & 0.077 & -0.030 & & 0.067 \\
\hline Estate (plantation) (d) & -0.627 & $* *$ & 0.274 & -0.231 & & 0.223 & -0.213 & & 0.185 & 0.025 & & 0.155 \\
\hline \multicolumn{13}{|c|}{ Province (default - Western) } \\
\hline Central & -0.214 & & 0.134 & -0.036 & & 0.129 & -0.372 & $* * *$ & 0.111 & -0.335 & $* * *$ & 0.098 \\
\hline Southern & -0.088 & & 0.128 & -0.056 & & 0.123 & -0.083 & & 0.099 & 0.045 & & 0.082 \\
\hline North and East & -0.075 & & 0.133 & -0.125 & & 0.127 & -0.944 & $* * *$ & 0.129 & -0.850 & $* * *$ & 0.114 \\
\hline North West & 0.244 & $* *$ & 0.123 & 0.266 & $* *$ & 0.120 & -0.155 & & 0.114 & 0.050 & & 0.091 \\
\hline North Central & -0.482 & $* *$ & 0.215 & 0.290 & $* *$ & 0.128 & -0.611 & $* * *$ & 0.176 & 0.011 & & 0.103 \\
\hline Uva & -1.181 & $* * *$ & 0.402 & -0.437 & $* *$ & 0.184 & -0.658 & $* * *$ & 0.175 & -0.641 & $* * *$ & 0.140 \\
\hline Sabaragamuwa & -0.773 & $* * *$ & 0.257 & -0.075 & & 0.139 & -0.490 & $* * *$ & 0.140 & -0.349 & $* * *$ & 0.112 \\
\hline \multicolumn{13}{|c|}{ Ethnicity (default - Sinhalese) } \\
\hline Sri Lankan Tamil (d) & 0.530 & $* * *$ & 0.117 & 0.148 & & 0.108 & 0.652 & $* * *$ & 0.109 & 0.038 & & 0.101 \\
\hline Indian Tamil (d) & 0.353 & & 0.354 & -0.352 & & 0.378 & 0.518 & $* *$ & 0.238 & -0.069 & & 0.221 \\
\hline
\end{tabular}


Moor (d)

Malay (d)

Burgher (d)

Other (d)

Constant

$\begin{array}{rlllllllllll}0.586 & * * * & 0.117 & 0.537 & * * * & 0.111 & 0.490 & * * * & 0.118 & 0.450 & * * * & 0.095 \\ 0.378 & & 0.472 & & & & 0.521 & & 0.431 & 0.116 & 0.500 \\ & & & 0.839 & * * & 0.411 & 0.266 & & 0.580 & 0.206 & & 0.537 \\ & & & 0.960 & * * & 0.471 & & & & & & \\ -2.801 & * * * & 0.224 & -2.176 & * * * & 0.201 & -2.274 & * * * & 0.204 & -1.355 & * * * & 0.167\end{array}$

$* \mathrm{p}<0.1, * * \mathrm{p}<0.05, * * * \mathrm{p}<0.001$ 